Article

\title{
Thermal Performance Enhancement of a Cross-Flow-Type Maisotsenko Heat and Mass Exchanger Using Various Nanofluids
}

\author{
Rasikh Tariq ${ }^{1}\left(\mathbb{D}\right.$, Changhong Zhan ${ }^{2, * \mathbb{D}}$, Nadeem Ahmed Sheikh ${ }^{3}(\mathbb{D})$ and Xudong Zhao ${ }^{4, *(\mathbb{D})}$ \\ 1 Facultad de Ingeniería, Universidad Autónoma de Yucatán, Av. Industrias No Contaminantes por Anillo \\ Periférico Norte, Apdo. Postal 150, Cordemex, Mérida, Yucatán 97000, Mexico; rasikhtariq@gmail.com \\ 2 School of Architecture, Harbin Institute of Technology; Key Laboratory of Cold Region Urban and Rural \\ Human Settlement Environment Science and Technology, Ministry of Industry and Information Technology, \\ Harbin 150001, China \\ 3 Department of Mechanical Engineering, Faculty of Engineering and Technology, International Islamic \\ University, Islamabad 44000, Pakistan; ndahmed@gmail.com \\ 4 School of Engineering and Computer Science, University of Hull, Hull HU6 7RX, UK \\ * Correspondence: zhan.changhong@hit.edu.cn (C.Z.); xudong.zhao@hull.ac.uk (X.Z.); Tel.: +86-451-8628-6336 \\ (C.Z.); +44-116-257-7971 (X.Z.); Fax: +86-451-8628-6338 (C.Z.); +44-116-257-7981 (X.Z.)
}

Received: 17 September 2018; Accepted: 27 September 2018; Published: 5 October 2018

\begin{abstract}
The incorporation of a Maisotsenko (M) Cycle into an indirect evaporative cooler has led to the achievement of sub-wet bulb temperature without any humidification, thus making it a possible green and sustainable alternative for handling the cooling load of a building. In this work, the thermal performance of a cross-flow heat and mass exchanger (HMX) is enhanced by the addition of nanoparticles in the wet channel because they significantly influence the heat and mass transfer characteristics of the base fluid. A governing model for the temperature and humidity variations of the HMX is numerically simulated. Initial benchmarking is achieved using water properties. Afterward, a comparative study is conducted using aluminum-oxide-, copper-oxide-, and titanium-oxide-based nanofluids. Enhancements of $24.2 \%$ in heat flux, $19.24 \%$ in wet bulb effectiveness, $7.04 \%$ in dew point effectiveness, $29.66 \%$ in cooling capacity, and $28.43 \%$ in energy efficiency ratio are observed by using alumina-based nanofluid as compared to water in the wet channel of the cross-flow HMX. Furthermore, a particle volume concentration of $1 \%$ and a particle diameter of $20 \mathrm{~nm}$ are recommended for maximum performance.
\end{abstract}

Keywords: Maisotsenko cycle; cross-flow HMX; nanofluid; heat transfer enhancement

\section{Introduction}

The global increase in $\mathrm{CO}_{2}$ levels and other environmental concerns (climate change, ozone layer depletion, etc.) have directed researchers to look for a substitute solution to meeting building cooling loads [1], which is conventionally dominated by the vapor-compression refrigeration cycle (VCRC) [2]. Despite their compactness and high coefficient of performance (COP), the use of high-power-consuming compressors and harmful chemical refrigerants makes VCRC the least favorable option for space cooling. To address this issue, studies have led towards an evaporative cooling system which uses the latent heat of vaporization of water for cooling purposes [3]. An evaporative cooling system is a low-carbon-emitting device [4] and has a natural refrigerant (i.e., water) [5]; therefore, it can provide an alternative solution to meeting building cooling requirements [6]. However, evaporative coolers face a technical barrier in overcoming enormous cooling loads because air cannot go below its wet bulb temperature while in direct contact with water [7]. 
Recent structural amendments and flow variations in indirect evaporative coolers (called the Maisotsenko or M Cycle) enabled them to achieve sub-wet bulb temperature without any moisture addition to the supply air provided to the occupant's comfort zone [8]. After this, many studies were performed on the structural design of the Maisotsenko (M)-cycle-based heat and mass exchanger (HMX) to find the optimal geometric and flow parameters to yield its maximum performance. Analyses based on cross-flow [9], counter-flow [10,11], and hybrid configurations [12] of HMXs are reported in the literature. Khalid et al. [13] experimentally analyzed the performance of a cross-flow HMX under low-velocity conditions. They concluded that the performance of the HMX can be enhanced by using an efficient moisture-absorbing material in the wet channel. Zhan et al. [14] analyzed a cross-flow HMX through numerical simulation and found the optimal geometric and flow parameters of the HMX.

Zhan et al. [15], Anisimov et al. [16], and Pandelidis et al. [17] each provided a comparative study of different configurations of HMXs. Their results have shown that a counter-flow HMX offers high cooling effectiveness but yields lower values of cooling capacity to handle a large cooling load. In contrast, a cross-flow configuration has higher values of cooling capacity at the detriment of other performance parameters. Afterwards, researchers focused on improving the energy efficiency of the dew point evaporative cooler [18-21]. For this purpose, some other structural modifications [12] were also presented in the HMX to increase the performance parameters; however, these structural modifications only increase the manufacturing complexities of the design. In a recent work by Tariq et al. [11], the wet fluid was altered from a conventional evaporating medium (water) to an alumina-based nanofluid. Research [22] has shown that the nanofluid exhibited higher thermal properties (thermal conductivity, viscosity, mass diffusivity, thermal diffusivity) compared with the base fluid. These enhanced properties yield a higher convective heat transfer coefficient in the wet channel and, as a result, the heat exchanger is expected to achieve higher performance parameters. However, nanofluids bring more complexities of type, concentration, size, and shape of the particles, as suggested by Maheshwary et al. [23]. Considering this aspect, Tariq et al. [11] replaced the water evaporating medium with a nanofluid in the wet channel of the indirect evaporative cooler. This alteration of the evaporating medium was only conducted for a counter-flow configuration of the indirect evaporative cooler, and their results indicated that the overall system performance was increased by $9-19 \%$ in terms of the energy efficiency ratio. However, this work was quite limited [11] because it was only applied to a counter-flow heat exchanger and analysis was presented for just one type of nanofluid (alumina-water) for a single particle diameter and concentration. Therefore, this area requires further concentration; specifically, no analysis is available for a cross-flow configuration for different types, concentrations, and particle diameter of nanofluids. This analysis is important because a cross-flow configuration is preferred for commercial and residential installation [24] of indirect evaporative coolers. Additionally, the selection of the most appropriate type of nanofluid is also not well researched. Therefore, in this article, the preceding literature gap is addressed.

In this work, the performance of a cross-flow HMX is enhanced by altering the heat and mass characteristics of the evaporation medium (water) in the wet channel. The alteration is achieved by the introduction of nanoparticles into the water. Some other studies have been conducted on these aforementioned complexities in different thermal systems including heat exchangers [25] and electronic cooling [26], etc. However, no work has been presented on the usage of nanoparticles in the wet channel of a cross-flow Maisotsenko-based HMX for performance enhancement.

The geometric and flow configuration of a cross-flow heat and mass exchanger is presented in Figure 1. The psychrometric representation is presented by the authors in [15]. In this work, an advancement is proposed for the conventional cross-flow HMX by using nanofluid in the wet channel (serving as an evaporating medium) of the cross-flow HMX. Analysis is carried out for three different types of nanoparticles—aluminum oxide, copper oxide, and titanium oxide- using a mathematical model developed for the cross-flow HMX. The heat and mass transfer characteristics (Nusselt number and Sherwood number) in the wet channel are calculated by incorporating the nanoparticle type, volume fraction, size, shape, and its Brownian motion. The resulting ordinary 
differential equations are simulated on MATLAB to find the temperature and humidity distribution of the channels with and without the addition of nanoparticles. A comparative study is conducted in which the influence of the type of nanoparticle on the HMX performance parameters (cooling effectiveness, cooling capacity, and Energy Efficiency Ratio (EER)) is conducted. Afterwards, analysis is carried out for varying particle volume fraction and particle diameter of one selected nanofluid.

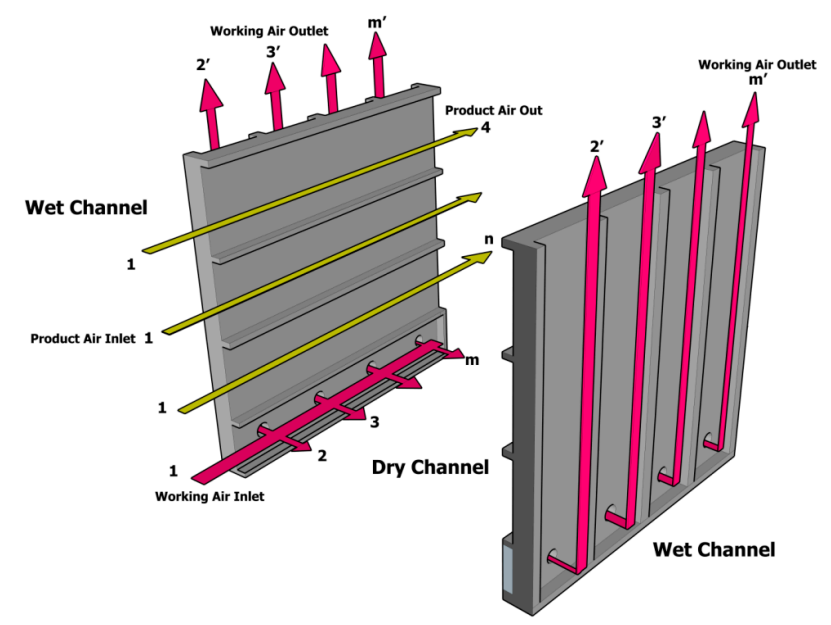

Figure 1. Schematic of the cross-flow heat and mass exchanger.

\section{Mathematical Description}

Energy and mass balance laws were applied to each channel to describe the mathematics of the heat and mass exchanger. For this purpose, a differential control volume (see Figure 2) was selected which shows the working air and the product air channel. The mathematical model of this system was developed for a single channel of each dry and wet section for numerical simplification. The working air in the dry channel moves in the $x$ direction whereas the working air in the wet channel moves in the $y$ direction. Therefore, the mathematical model was developed to incorporate two one-dimensional flows. Here, all flows are considered to be steady-state. The mixing and spatial distributions of nanoparticles are considered uniform. The properties of the fluid are considered to be consistent at any cross section of the dry and wet channels. The entry hydrodynamic layer is ignored. The water vapor is assumed to be uniformly distributed in the wet channel. Furthermore, considering the applied nature of the problem, it is also assumed that there is no loss of nanoparticles from the water film to the working air, the nanofluid is stable, the distribution of the nanoparticles in the base fluid is consistent, and there are no problems with sedimentation of nanoparticles. Zhan et al. [14] showed that some of these assumptions do not have any significant influence on the overall performance of the HMX.

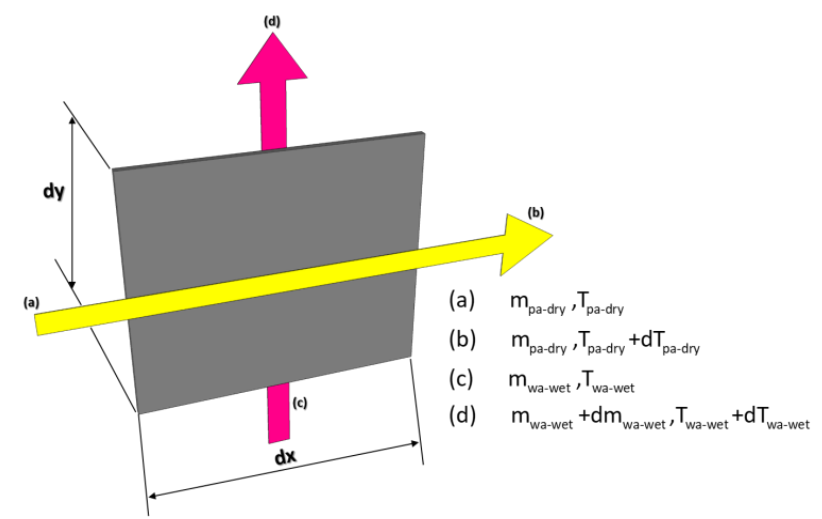

Figure 2. Control volume selected for development of the mathematical model, showing product air channel and working air wet channel. 


\subsection{Energy and Mass Balance Laws}

The energy balance works on the basis that the change in enthalpy of the fluid is equal to the corresponding mode of heat transfer. The product air in the dry channel undergoes a sensible change in temperature and this thermal change is caused because heat is transferred to the adjacent wet channel through the convective mode of heat transfer. Similarly, the enthalpy change of the working air in the wet channel is caused by heat addition from the product air channel. Based on this, the temperature and humidity distribution equations of the air channels are given in Table 1.

Table 1. Energy and mass balance laws applied to different channels of the heat and mass exchanger (HMX).

\begin{tabular}{|c|c|c|}
\hline $\begin{array}{c}\text { Parameter } \\
\text { Energy Balance }\end{array}$ & \multicolumn{2}{|l|}{ Equation } \\
\hline $\begin{array}{l}\text { Product Air Channel } \\
\text { (Temperature Distribution) }\end{array}$ & $\frac{\partial \mathrm{T}_{\mathrm{pa}-\mathrm{dry}}}{\partial \mathrm{x}}=\frac{\mathrm{h}_{\mathrm{pa}-\mathrm{dry}} \times \partial \mathrm{y}}{\mathrm{m}_{\mathrm{pa}-\mathrm{dry}} \mathrm{c}_{\mathrm{p}-\mathrm{pa}-\mathrm{dry}}}\left(\mathrm{T}_{\mathrm{pa}-\mathrm{dry}}-\mathrm{T}_{\mathrm{wa}-\mathrm{wet}}\right)$ & (1) \\
\hline $\begin{array}{l}\text { Working Air Dry Channel } \\
\text { (Temperature Distribution) }\end{array}$ & $\frac{\partial \mathrm{T}_{\mathrm{wa}-\mathrm{dry}}}{\partial \mathrm{x}}=\frac{\mathrm{h}_{\mathrm{wa}-\mathrm{dry}} \times \partial \mathrm{y}}{\mathrm{m}_{\mathrm{wa}-\mathrm{dry}} \mathrm{c}_{\mathrm{p}-\mathrm{wa}-\mathrm{dry}}}\left(\mathrm{T}_{\mathrm{wa}-\mathrm{dry}}-\mathrm{T}_{\mathrm{wa}-\mathrm{wet}}\right)$ & (2) \\
\hline $\begin{array}{l}\text { Working Air Wet Channel } \\
\text { (Temperature Distribution) }\end{array}$ & 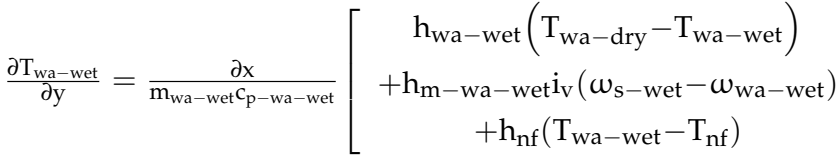 & (3) \\
\hline \multicolumn{3}{|c|}{ Mass Balance Equation: } \\
\hline $\begin{array}{l}\text { Working Air Wet Channel } \\
\text { (Humidity Distribution) }\end{array}$ & 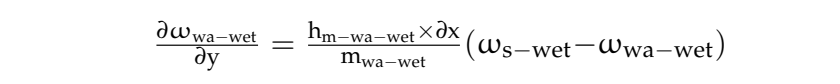 & (4) \\
\hline
\end{tabular}

Equations (1), (2), and (4) (Table 1) are first-order ordinary differential equations (ODEs) having three unknowns, i.e., the temperature of product air, and the temperature and humidity of working air in the wet channel. The inlet temperatures of the product air and working air and the humidity of the working air are considered to be the boundary conditions for Equations (1), (2) and (4). Furthermore, the mixer equation from the working air dry channel to the working air wet channel was solved using the method adapted by Demis et al. [27].

\subsection{Calculation of Heat and Mass Transfer Parameters of the HMX}

The physics of the air-water-nanoparticle mixture are such that the properties of the evaporating medium (which is water originally) are altered by the properties of the nanofluid. Consider the fact that the multiphase nature of particulate flow requires rigorous mathematical models [28]; furthermore, simplified models [29] are extensively employed to simulate the nature of similar flows in the limit of low concentration and small particle diameters. The current investigation involving nanofluids remains well within the prescribed limits for the reliable applicability of simplified models. Therefore, this study uses a homogeneous model approach for the presented results. Maxwell [30] correlation was used to find the effective thermal conductivity of the nanofluid. The viscosity of the nanofluid was calculated using the correlation proposed by Corcione [31] considering the limitations of the particle size, particle volume fraction, and the working temperature. Other thermophysical quantities including the specific heat, density, mass diffusivity, and thermal diffusivity of the nanofluid were calculated using a weighted-average method considering the concentration of nanoparticles in the base fluid [29]. Finally, the convective heat transfer coefficient of the water film was calculated using the correlation provided by Xuan and Li [32]. Further details of this procedure are shown in Table 2. The convective heat transfer coefficient of the dry and wet air, along with the convective mass transfer coefficient between the wet air and evaporating medium, is shown by the authors in [14,15]. 
Table 2. Details of the calculation of the heat and mass transfer parameters of the fluids.

\begin{tabular}{|c|c|c|}
\hline Parameter & Equation & \\
\hline \multicolumn{3}{|c|}{ Product Air and Working Air Dry Channel } \\
\hline Hydraulic Diameter & $\mathrm{D}_{\mathrm{h}-\mathrm{pa}-\mathrm{dry}}=\mathrm{D}_{\mathrm{h}-\mathrm{wa}-\mathrm{dry}}=\frac{4(\mathrm{~b} \times \mathrm{a})}{(2 \mathrm{a}+2 \mathrm{~b})}$ & (5) \\
\hline Reynolds Number & $\operatorname{Re}_{\mathrm{pa}-\mathrm{dry}}=\operatorname{Re}_{\mathrm{wa}-\mathrm{dry}}=\frac{\rho_{\mathrm{wa}} \mathrm{v} \mathrm{D}_{\mathrm{h}-\mathrm{wa}-\mathrm{dry}}}{\mu_{\mathrm{wa}}}$ & (6) \\
\hline Nusselt Number [33] & $\mathrm{Nu}_{\mathrm{pa}-\text { dry }}=\mathrm{Nu}_{\mathrm{wa}-\text { dry }}=1.86\left(\frac{\mathrm{Re}_{\mathrm{wa}-\mathrm{dry}} \times \operatorname{Pr}_{\mathrm{wa}}}{\mathrm{L} / \mathrm{D}_{\mathrm{h}-\mathrm{wa}-\mathrm{dry}}}\right)^{\frac{1}{3}}\left(\frac{\mu_{\mathrm{wa}}}{\mu_{\mathrm{s}-\mathrm{wa}}}\right)^{0.14}$ & (7) \\
\hline Convective Heat Transfer Coefficient & $\mathrm{h}_{\mathrm{pa}-\mathrm{dry}}=\mathrm{h}_{\mathrm{wa}-\mathrm{dry}}=\frac{\mathrm{Nu}_{\mathrm{wa}-\mathrm{dry}} \times \mathrm{k}_{\mathrm{wa}-\mathrm{dry}}}{\mathrm{D}_{\mathrm{h}-\mathrm{wa}-\mathrm{dry}}}$ & (8) \\
\hline \multicolumn{3}{|c|}{ Working Air Wet Channel } \\
\hline Hydraulic Diameter & $\mathrm{D}_{\mathrm{h}-\mathrm{wa}-\text { wet }}=\frac{4(\mathrm{a} \times \mathrm{L})}{(2 \mathrm{~L}+2 \mathrm{a})}$ & (9) \\
\hline Reynolds Number & $\operatorname{Re}_{\text {wa-wet }}=\frac{\rho_{\text {wa }} v D_{h-w a-w e t}}{\mu_{\text {wa }}}$ & $(10)$ \\
\hline Nusselt Number [33] & $\mathrm{Nu}_{\text {wa-wet }}=1.86\left(\frac{\mathrm{Re}_{\text {wa-wet }} \times \operatorname{Pr}_{\text {wa }}}{\mathrm{L} / \mathrm{D}_{\mathrm{h}-\text { wa }- \text { wet }}}\right)^{\frac{1}{3}}\left(\frac{\mu_{\text {wa }}}{\mu_{\mathrm{s}-\text { wa }}}\right)^{0.14}$ & $(11)$ \\
\hline Convective Heat Transfer Coefficient & $\mathrm{h}_{\mathrm{wa}-\text { wet }}=\frac{\mathrm{Nu}_{\mathrm{wa}-\text { wet }} \times \mathrm{k}_{\mathrm{wa}-\text { wet }}}{\mathrm{D}_{\mathrm{h}-\mathrm{wa}-\mathrm{wet}}}$ & $(12)$ \\
\hline Mass Diffusivity of Nanofluid [34] & $\left.\mathcal{D}_{\mathrm{nf}}=(1-\phi)\right) \mathcal{D}_{\mathrm{w}}$ & $(13)$ \\
\hline $\begin{array}{l}\text { Mass Diffusivity of Nanofluid and Air } \\
\text { [35] }\end{array}$ & $\mathcal{D}_{\text {wa-nf }}=21.2 \times 10^{-6}\left[1+\left(0.0071 \times \mathrm{T}_{\text {wa-wet }}\right)\right]$ & $(14)$ \\
\hline Schmidt Number & $\mathrm{Sc}_{\mathrm{wa}-\mathrm{nf}}=\frac{\mu_{\mathrm{wa}}}{\mathcal{D}_{\mathrm{wa}-\mathrm{nf}}}$ & $(15)$ \\
\hline Sherwood Number [36] & 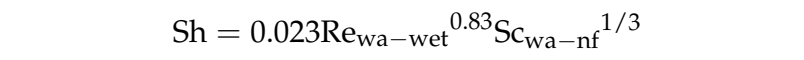 & $(16)$ \\
\hline Convective Mass Transfer Coefficient & $\mathrm{h}_{\mathrm{m}-\text { wa }- \text { wet }}=\frac{\mathrm{Sh} \times \mathrm{k}_{\mathrm{wa}-\text { wet }}}{\mathrm{D}_{\mathrm{h}-\text { wa }- \text { wet }}}$ & $(17)$ \\
\hline \multicolumn{3}{|c|}{ Nanofluid Properties } \\
\hline Thermal Conductivity [37] & $\mathrm{k}_{\mathrm{nf}}=\mathrm{k}_{\mathrm{w}} \frac{\mathrm{k}_{\mathrm{p}}+2 \mathrm{k}_{\mathrm{w}}+2 \phi\left(\mathrm{k}_{\mathrm{p}}-\mathrm{k}_{\mathrm{w}}\right)}{\mathrm{k}_{\mathrm{p}}+2 \mathrm{k}_{\mathrm{w}}-\phi\left(\mathrm{k}_{\mathrm{p}}-\mathrm{k}_{\mathrm{w}}\right)}$ & $(18)$ \\
\hline Specific Heat [38] & $c_{p-n f}=\phi c_{p-p}+(1-\phi) c_{p-w}$ & $(19)$ \\
\hline Density [38] & $\rho_{\mathrm{nf}}=\phi \rho_{\mathrm{p}}+(1-\phi) \rho_{\mathrm{w}}$ & $(20)$ \\
\hline \multirow[t]{2}{*}{ Thermal Diffusivity [39] } & $\alpha_{\mathrm{nf}}=\frac{\mathrm{k}_{\mathrm{nf}}}{(1-\phi)\left(\rho_{\mathrm{w}} \mathrm{c}_{\mathrm{p}-\mathrm{w}}\right)+\phi\left(\rho_{\mathrm{p}} \mathrm{c}_{\mathrm{p}-\mathrm{p}}\right)}$ & $(21)$ \\
\hline & $\mu_{\mathrm{nf}}=\mu_{\mathrm{w}}\left[1-34.87\left(\mathrm{~d}_{\mathrm{p}} / \mathrm{d}_{\mathrm{w}}\right)^{-0.3} \phi^{1.03}\right]^{-1}$ & \\
\hline Viscosity [31] & Range : $\left[\begin{array}{c}0.2 \% \leq \phi \leq 9 \% \\
10 \mathrm{~nm} \leq \mathrm{d}_{\mathrm{p}} \leq 150 \mathrm{~nm} \\
294 \mathrm{~K} \leq \mathrm{T} \leq 324 \mathrm{~K}\end{array}\right]$ & $(22)$ \\
\hline Prandtl Number of Nanofluid & $\operatorname{Pr}_{\mathrm{nf}}=\frac{\mathrm{c}_{\mathrm{p}-\mathrm{nf}} \times \mu_{\mathrm{nf}}}{\mathrm{k}_{\mathrm{nf}}}$ & $(23)$ \\
\hline Brownian Motion [40] & $\mathrm{V}_{\mathrm{BR}}=\frac{\kappa_{\mathrm{B}} \mathrm{T}_{\mathrm{w}}}{3 \pi \mu_{\mathrm{nf}} \mathrm{d}_{\mathrm{p}} \lambda_{\mathrm{w}}}$ & $(24)$ \\
\hline Reynolds Number & $\operatorname{Re}_{\mathrm{p}}=\frac{\rho_{\mathrm{w}} \mathrm{V}_{\mathrm{BR}} \mathrm{d}_{\mathrm{p}}}{\mu_{\mathrm{w}}}$ & $(25)$ \\
\hline Peclet Number [41] & $P e_{p}=\frac{v \times d_{p}}{\alpha_{n f}}$ & $(26)$ \\
\hline Nusselt Number (Laminar) [32] & $\mathrm{Nu}_{\mathrm{nf}}=0.4328\left(1.0+11.285 \phi^{0.754} \mathrm{Pe}_{\mathrm{p}}^{0.218}\right) \operatorname{Re}_{\mathrm{p}}^{0.333} \operatorname{Pr}_{\mathrm{nf}}^{0.4}$ & $(27)$ \\
\hline Convective Heat Transfer Coefficient & $\mathrm{h}_{\mathrm{nf}}=\frac{\mathrm{Nu}_{\mathrm{nf}} \times \mathrm{k}_{\mathrm{nf}}}{\mathrm{D}_{\mathrm{h}-\mathrm{wa}-\text { wet }}}$ & $(28)$ \\
\hline
\end{tabular}

\subsection{Performance Parameters}

The cooling effectiveness of the HMX was calculated using

$$
\varepsilon_{\mathrm{WB}}=\frac{\mathrm{T}_{\mathrm{DB}-\mathrm{wa}-\text { dry,inlet }}-\mathrm{T}_{\mathrm{DB}-\mathrm{wa} \text {,outlet }}}{\mathrm{T}_{\mathrm{DB}-\mathrm{wa}-\text { dry,inlet }}-\mathrm{T}_{\mathrm{WB}-\mathrm{wa}-\text { dry,inlet }}}
$$




$$
\varepsilon_{\mathrm{DP}}=\frac{\mathrm{T}_{\mathrm{DB}-\mathrm{wa}-\text { dry,inlet }}-\mathrm{T}_{\mathrm{DB}-\text { wa,outlet }}}{\mathrm{T}_{\mathrm{DB}-\mathrm{wa}-\text { dry,inlet }}-\mathrm{T}_{\mathrm{DP}-\text { wa }- \text { dry,inlet }}}
$$

The cooling capacity was calculated using

$$
\Psi=\mathrm{m}_{\mathrm{wa}-\mathrm{dry}}\left(\mathrm{H}_{\mathrm{wa}-\mathrm{dry} \text {,inlet }}-\mathrm{H}_{\mathrm{wa} \text {,outlet }}\right)
$$

The performance of the HMX was gauged based on the wet bulb effectiveness, dew point effectiveness, cooling capacity, and energy efficiency ratio [42]. The Energy Efficiency Ratio (EER) was calculated using the ratio of cooling capacity to the total required input power. The required input power was evaluated by accounting for the major losses in the channels such as friction factor. The performance of the HMX was also deduced by comparing water as the working fluid in the wet channel with the nanofluid. Therefore, each of the performance indices (PIs) for using nanofluid in the wet channel were compared with the performance indices of using water in the wet channel and are represented by the Performance Enhancement Ratio (PER).

$$
\operatorname{PER}(\%)=\frac{\mathrm{PI}_{\mathrm{nf}}-\mathrm{PI}_{\mathrm{w}}}{\mathrm{PI}_{\mathrm{w}}} \times 100
$$

\section{Validation of Numerical Approach}

Equations (1)-(4) are the main equations which were used to find the temperature and humidity distribution of the fluids. These equations were discretized using a first-order finite difference formulation. The resulting algebraic equations were simulated on MATLAB using appropriate boundary conditions. A convergence study was conducted and the relative error was calculated for the product air outlet temperature using the temperature of previous space-step iteration. A schematic description of the methodology is shown in Figure 3.

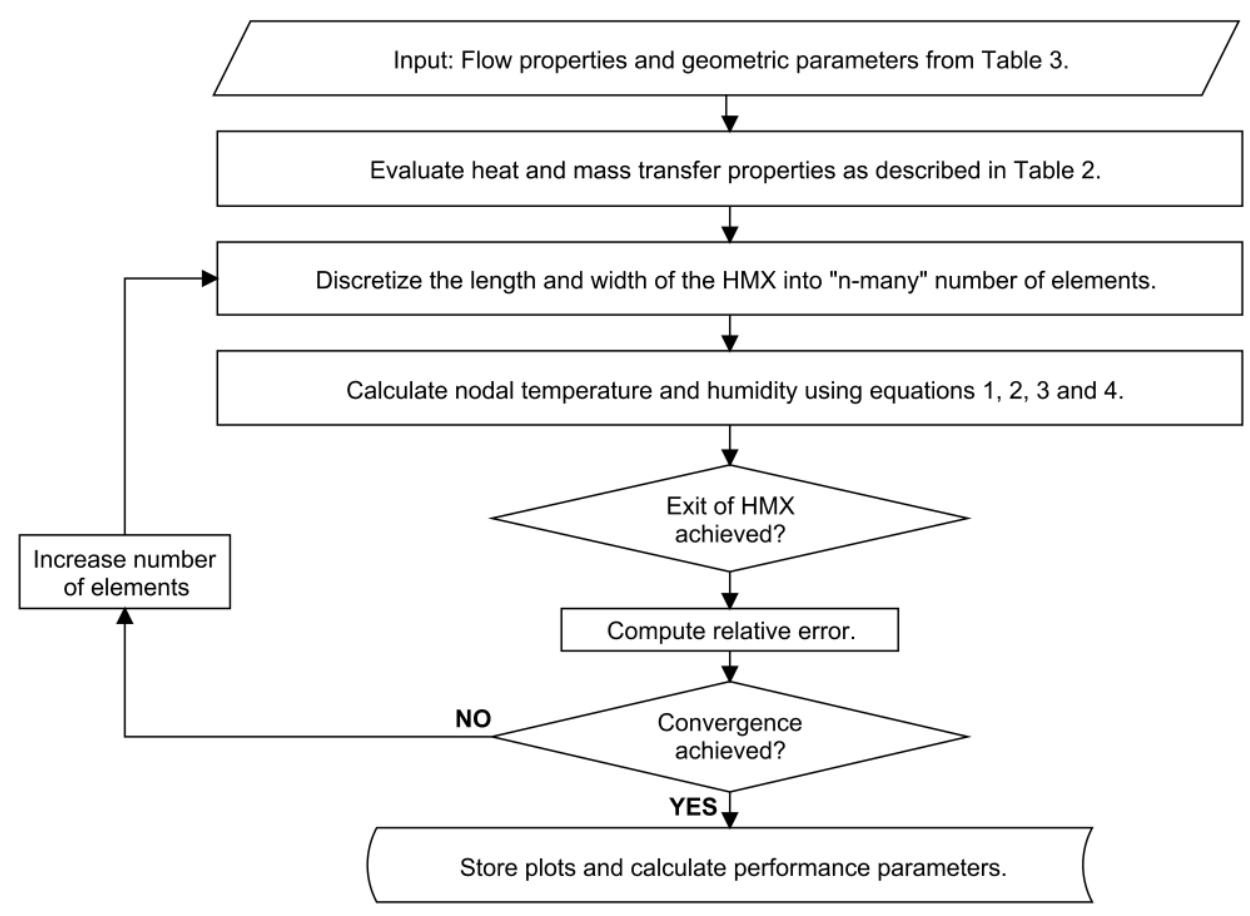

Figure 3. Methodology diagram of the numerical approach.

The results of this study were validated in two parts, as described in the following sections. However, it must be stressed that both of the configurations analyzed in Sections 3.1 and 3.2 are cross-flow configurations of the M Cycle. 


\subsection{Comparison with an M50 Air Cooler [43] (Part I)}

In this section, a validation study was conducted comparing the current numerical work with the experimental results [22] of an HMX manufactured by Coolorado Corporation [43]. The operating and geometric conditions for the experimental results of [22] are given in Table 3.

Table 3. Operating and geometric parameters for the experimental results of [22].

\begin{tabular}{cccc}
\hline No. & Parameters & Quantity & Units \\
\hline 1 & Intake air flow rate & 1095 to 4050 & $\mathrm{~m}^{3} / \mathrm{h}$ \\
2 & Supply-to-working air flow rate ratio & $1: 1$ & - \\
3 & Inlet air temperature & 17.3 to 32.3 & ${ }^{\circ} \mathrm{C}$ \\
4 & Inlet relative humidity & 7.4 to 62.9 & $\%$ \\
5 & Number of product air channels & 39 & - \\
6 & Product air channel height & 3.81 & $\mathrm{~mm}$ \\
7 & Working air channel height & 2.54 & $\mathrm{~mm}$ \\
8 & Channel width & 23.4 & $\mathrm{~mm}$ \\
\hline
\end{tabular}

Additionally, the details of the instrumentation utilized in the experimental testing of [22] are shown in Table 4.

Table 4. Details of instrumentation for the experimental testing in [22].

\begin{tabular}{|c|c|c|c|c|}
\hline No. & Instrument & Usage & Accuracy & Manufacturer \\
\hline 1 & HMP45C temperature sensor & $\begin{array}{l}\text { To measure the temperature of } \\
\text { working air and product air. } \\
\text { To measure the relative }\end{array}$ & $0.05^{\circ} \mathrm{C}$ & Campbell Scientific \\
\hline 2 & HMP45C humidity sensor & $\begin{array}{l}\text { humidity of working air and } \\
\text { product air. }\end{array}$ & $2 \%$ & Campbell Scientific \\
\hline 3 & ZW-007 temperature sensor & $\begin{array}{c}\text { To measure the inlet air } \\
\text { temperature. }\end{array}$ & $0.21^{\circ} \mathrm{C}$ & $\mathrm{HOBO}$ \\
\hline 4 & ZW-007 humidity sensor & $\begin{array}{l}\text { To measure the inlet air } \\
\text { relative humidity. }\end{array}$ & $2.5 \%$ & НОВО \\
\hline 5 & 407123 hot wire anemometers & $\begin{array}{l}\text { To measure the velocity profile } \\
\text { of the air flow. }\end{array}$ & $3.0 \%$ & Extech Instruments \\
\hline 6 & $\begin{array}{l}\text { Fieldpiece HS26 stick meter } \\
\text { with thermocouple ATH4 } \\
\text { accessory head }\end{array}$ & $\begin{array}{l}\text { To measure the temperature of } \\
\text { the HMX filling surface. }\end{array}$ & $1{ }^{\circ} \mathrm{C}$ & Fieldpiece \\
\hline
\end{tabular}

All the sensors reported in Table 4 were connected to a CR10X data logger (manufacturer: Campbell Scientific) and a computer recorded the data after every three minutes. Weerts's [22] experiments were not performed to give the direct trends in the product air or the working air; therefore, a correlation method [27] was used for the validation of the results. Through a few trial calculations, for this case, the convergence criteria is set to be 0.001 ; therefore, the HMX was divided into 800 elements in the $x$ direction and 860 elements in the $y$ direction, making a grid of 688,000 cells. On this grid, the outlet temperature of the product air, the outlet temperature of the working air, and the outlet absolute humidity of the working air were recorded. The correlation-based validation is shown in Figure $4 \mathrm{a}-\mathrm{c}$ ) for the product air outlet temperature, working air outlet temperature, and working air absolute humidity (respectively). 
(a)

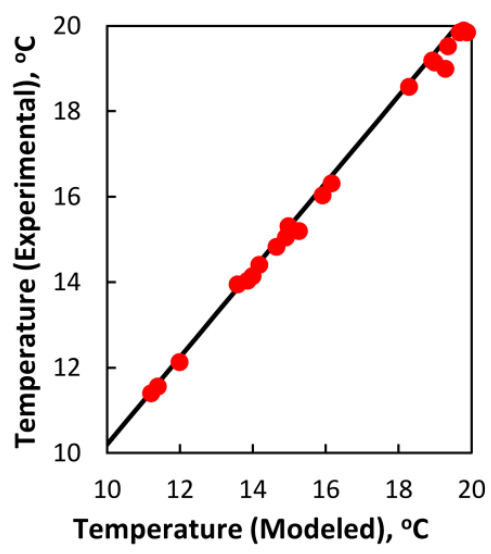

Weerts Experimental Data

(b)

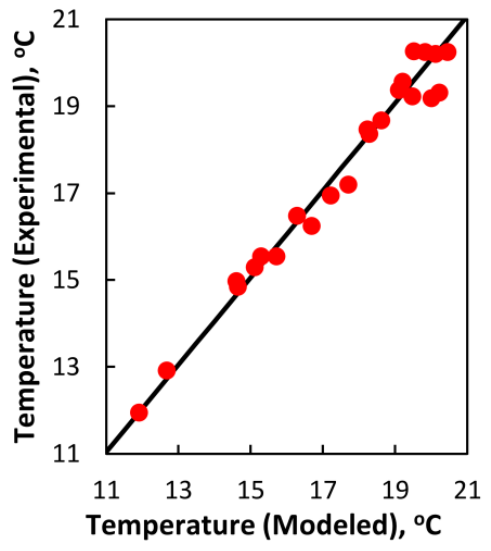

(c)

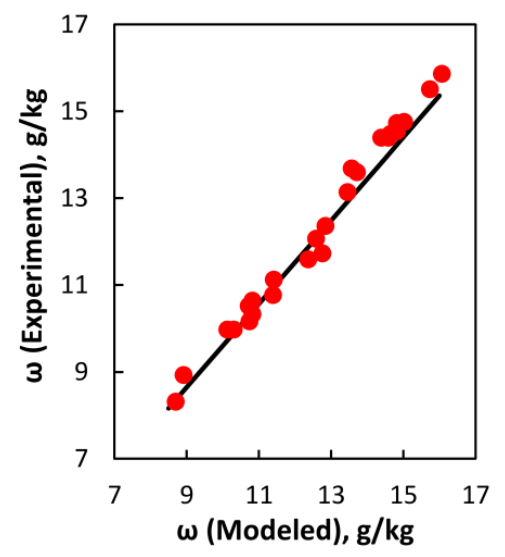

Figure 4. Correlation-based validation with Weerts's data [22] for (a) product air outlet temperature;

(b) working air outlet temperature; and (c) working air outlet absolute humidity.

\subsection{Comparison with a TAC-150 [44] (Part II)}

In this section, the validation of the results was conducted as a comparison with a TAC-150 air cooler developed by ISAW Corporation Limited [44]. Qui [45] experimentally analyzed the TAC-150 air cooler. The experimental conditions from Qui's [45] work are presented in Table 5.

Table 5. Operating and geometric parameters for the experimental results from Qui [45].

\begin{tabular}{cccc}
\hline No. & Parameters & Quantity & Units \\
\hline 1 & Relative humidity of inlet air & 50 & $\%$ \\
2 & Dry bulb temperature of inlet air & $25-45$ & ${ }^{\circ} \mathrm{C}$ \\
3 & Overall dimensions & $270 \times 290 \times 250$ & $\mathrm{~mm}^{3}$ \\
4 & Length of primary air section & 192 & $\mathrm{~mm}$ \\
5 & Number of dry channels & 7 & - \\
\hline
\end{tabular}

The overall dimensions of the HMX used in the TAC-150 cooler are $270 \times 290 \times 250 \mathrm{~mm}^{3}$, and it has a length of $192 \mathrm{~mm}$ for the primary air stream. The lower half of the intake side which has a length of $82 \mathrm{~mm}$ contains the dry and wet channels. A further $8 \mathrm{~mm}$ length is left towards both halves of the intake air length, thus making a total of $290 \mathrm{~mm}$ in length and 7 dry channels. The details of the testing instruments used in the experimentation by Qui [45] are presented in Table 6.

Table 6. Details of instrumentation for the experimental testing by Qui [45].

\begin{tabular}{ccccc}
\hline No. & Instrument & Usage & Accuracy & Manufacturer \\
\hline \multirow{2}{*}{1} & HMP45A & To measure the & Operating range: $-40{ }^{\circ} \mathrm{C}$ to $+50{ }^{\circ} \mathrm{C}$ & \\
& hygrometer & temperature of & Storage temperature range: $-40{ }^{\circ} \mathrm{C}$ to $+80{ }^{\circ} \mathrm{C}$ & Vaisala \\
& sensor & air flow. & Settling time: $500 \mathrm{~ms}$ & \\
HMP45A & To measure the & Operating range: $0.8 \%$ to $100 \%$ & Vaisala \\
& hygrometer & relative humidity & Accuracy: $(1) \pm 2 \%$ RH for $0-90 \%$ of range. & \\
& sensor & of air flow. & (2) $\pm 3 \%$ RH for $90-100 \%$ of range. & \\
\hline
\end{tabular}

The instrumentation presented in Table 6 was connected to a data-logging system with name code DT500. Further details of the experimentation procedure can be found in [45]. Through a few trial calculations, for this case, the convergence criteria is set to be 0.001 ; therefore, the HMX was divided into 450 elements in the $x$ direction and 560 elements in the $y$ direction, making a grid of 252,000 cells. The comparison is presented in Figure 5. The level of agreement between these results gives sufficient confidence that the mathematical modeling of the air flow and heat transfer is reliable. 


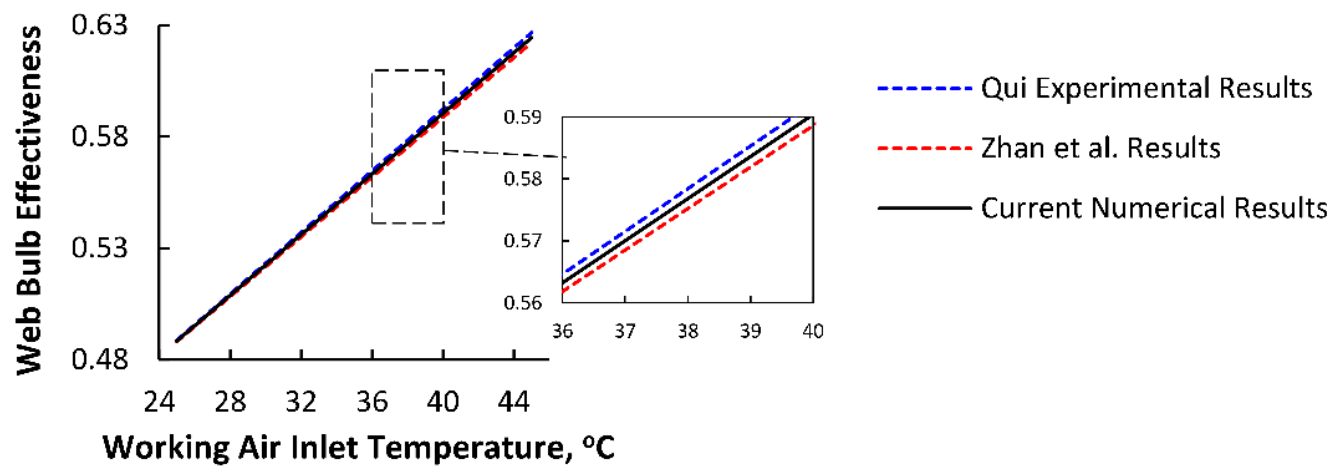

Figure 5. Validation of results (Part II): comparison of numerical results with the experiment results from Qui [45] and numerical results from Zhan et al. [14] for $\mathrm{RH}=35 \%$, dry bulb temperature of working air $=25^{\circ} \mathrm{C}$ to $45^{\circ} \mathrm{C}$, and volume flow rate $=130 \mathrm{~m}^{3} / \mathrm{h}$.

\section{Modelling Setup}

Simulations for the current analysis were carried out using nanofluid as an evaporation medium after the detailed benchmarking carried out in Section 3. The governing equations (Table 1) were discretized using a first-order finite difference formulation. The convergence criterion was set to 0.001; therefore, a total of 1300 elements in the $x$ direction and 1,456 elements in the $y$ direction were solved, giving 1,892,800 cells. The thermophysical properties of the nanofluid were extracted from Engineering Equation Solver (EES) [46]. Other geometric and operating parameters are presented in Table 7.

Table 7. Input parameters for the simulation.

\begin{tabular}{cccc}
\hline No. & Parameters & Quantity & Units \\
\hline 1 & Working Air Inlet DB Temperature & 35 & ${ }^{\circ} \mathrm{C}$ \\
2 & Working Air Inlet Absolute Humidity & 11.2 & $\mathrm{~g} / \mathrm{kg}$ \\
3 & Total Flow Rate of Inlet Air & 228 & $\mathrm{~m}^{3} / \mathrm{h}$ \\
4 & Product Air Flow Rate & 150 & $\mathrm{~m}^{3} / \mathrm{h}$ \\
5 & Working Air Flow Rate & 78 & $\mathrm{~m}^{3} / \mathrm{h}$ \\
6 & Particle Volume Fraction & 0.8 & $\%$ \\
7 & Diameter of Nanoparticles & 20 & $\mathrm{~nm}$ \\
8 & Length of Dry Channels & 1 & $\mathrm{~m}$ \\
9 & Length of Wet Channels & 1 & $\mathrm{~m}$ \\
10 & Width of Channels & 314 & $\mathrm{~mm}$ \\
11 & Height of Channels & 5 & $\mathrm{~mm}$ \\
12 & Working Air Dry Channels & 33 & - \\
13 & Product Air Dry Channels & 5 & - \\
14 & Working Air Wet Channels & 32 & - \\
\hline
\end{tabular}

\section{Results and Discussion}

\subsection{Heat and Mass Transfer Characteristics of the HMX}

The heat and mass transfer characteristics of the HMX are explained in terms of the temperature and humidity distribution for four kinds of evaporation media (water, $\mathrm{CuO}$ nanofluid, $\mathrm{TiO}_{2}$ nanofluid, and $\mathrm{Al}_{2} \mathrm{O}_{3}$ nanofluid) in dry and wet channels as described in Figure 6a-d.

The working air enters the HMX at $35^{\circ} \mathrm{C}$ having a wet bulb temperature of $21.99{ }^{\circ} \mathrm{C}$ and a dew point temperature of $15.77^{\circ} \mathrm{C}$. It is observed, generally, that the working air in the dry channel achieves a lower temperature as compared with the product air channels, as described in Figure 6 (a1, b1, c1, d1), because of the flow rate decrement in the dry channel as fluid is diverted towards the wet channel. Furthermore, the air in some initial channels of the product air leaves the HMX at lower temperatures compared with the product air leaving the last channels. A 7\% increment in the temperature of the product air is observed while moving from product air channel 1 to product air channel 33 using 
water as the evaporation medium; this was also observed by Weerts [22] in their experimental results. Furthermore, it is observed that the average exit temperature of the product air from all channels is $23.9^{\circ} \mathrm{C}$ for water, $22.9^{\circ} \mathrm{C}$ for $\mathrm{CuO}$ nanofluid, $\sim 22^{\circ} \mathrm{C}$ for $\mathrm{TiO}_{2}$ nanofluid, and $20.8^{\circ} \mathrm{C}$ for $\mathrm{Al}_{2} \mathrm{O}_{3}$ nanofluid. This indicates that the original design of the HMX cannot achieve a sub-wet bulb temperature using the parameters mentioned in Table 1. However, the HMX can achieve sub-wet bulb temperature by using either $\mathrm{TiO}_{2}$ or $\mathrm{Al}_{2} \mathrm{O}_{3}$ nanofluid as an evaporation medium in the wet channel.

The working air in the dry channel is drawn to the working air wet channels. It can be observed in Figure $6(\mathrm{a} 2, \mathrm{~b} 2, \mathrm{c} 2, \mathrm{~d} 2)$ that the inlet temperature of the working air in the wet channel is equal to the air temperature leaving the working air-dry channels. Such a behavior of the temperature distribution of the wet air was also reported by Bolotin et al. [47] for a cross-flow HMX. For wet air channel 1 (using water), the working air enters at a temperature of $34.3^{\circ} \mathrm{C}$ and attain its wet bulb temperature $\left(21.8^{\circ} \mathrm{C}\right)$ at a channel width ratio of $70 \%$. After this condition (saturation condition), the working air absorbs heat from the adjacent product air channels, causing an elevation in its temperature, and leaves the HMX at $\sim 25^{\circ} \mathrm{C}$. However, as the count of the wet channels increases from 1 to 32 , the saturation length is decreased because the working air in wet channel 32 enters at the lowest temperature (i.e., 22.9 $\left.{ }^{\circ} \mathrm{C}\right)$. Therefore, we can observe a decrease in saturation length while increasing the count of wet channels for each of Figure 6 (a2, b2, c2, d2). However, one important phenomenon observed here is that the saturation length of the working air also varies under the addition of nanofluids, i.e., the saturation length in wet channel 1 is $69 \%$ for the $\mathrm{CuO}$ nanofluid, $68 \%$ for the $\mathrm{TiO}_{2}$ nanofluid, and $66 \%$ for the $\mathrm{Al}_{2} \mathrm{O}_{3}$ nanofluid. It is also observed that the exit temperature of the nanofluid-based evaporation media is high compared with that of water because of the enhanced heat and mass characteristics of the nanofluids. The temperature of the working air at the exit of the wet channels using alumina nanofluid is higher than that of the other two types, which signifies the lower product air temperature for alumina-based nanofluid because the working air absorbs more heat in the case of alumina nanoparticles.

The humidity distributions of the working air in the wet channel for all types of evaporation media are shown in Figure 6 (a3, b3, c3, d3). The humidity is increasing with the wet air flow direction because of the constant moisture addition from the evaporation medium. The saturation conditions of the wet air can also be described here, as it can be observed that the starting channels of the wet air need more length to reach saturation; however, the requirement of the saturation length is decreased with the increase in wet channel count. Similarly, it is also observed that the saturation length is decreased by using either $\mathrm{CuO}-, \mathrm{TiO}_{2^{-}}$, or $\mathrm{Al}_{2} \mathrm{O}_{3}$-based nanofluid. Once the saturation is achieved, the working air only absorbs the amount of moisture that is required to keep it saturated in the wet channel. The average exit humidity of air from all wet channels is $\sim 23.6 \mathrm{~g} / \mathrm{kg}$ for water, $24.5 \mathrm{~g} / \mathrm{kg}$ for $\mathrm{CuO}$ nanofluid, $25.20 \mathrm{~g} / \mathrm{kg}$ for $\mathrm{TiO}_{2}$ nanofluid, and $26.2 \mathrm{~g} / \mathrm{kg}$ for $\mathrm{Al}_{2} \mathrm{O}_{3}$-based nanofluid.

This differences in the temperature and humidity plots of all four kinds of evaporation media are observed because of their differences in thermo-physical properties including thermal conductivity, thermal diffusivity, and heat capacity. These differences in the thermophysical properties correspond to the enhanced heat and mass transfer characteristics of the nanofluids over ordinary water. Since the thermo-physical properties of $\mathrm{Al}_{2} \mathrm{O}_{3}$-based nanofluid are significantly higher than those of the other types, the product air temperature is lower at the exit of the dry channels, and the working air temperature and humidity are high at the exit of wet channels as compared to those for other nanofluids. 

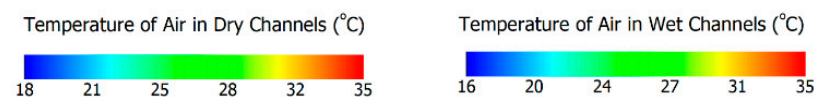

(a2)

(a3)
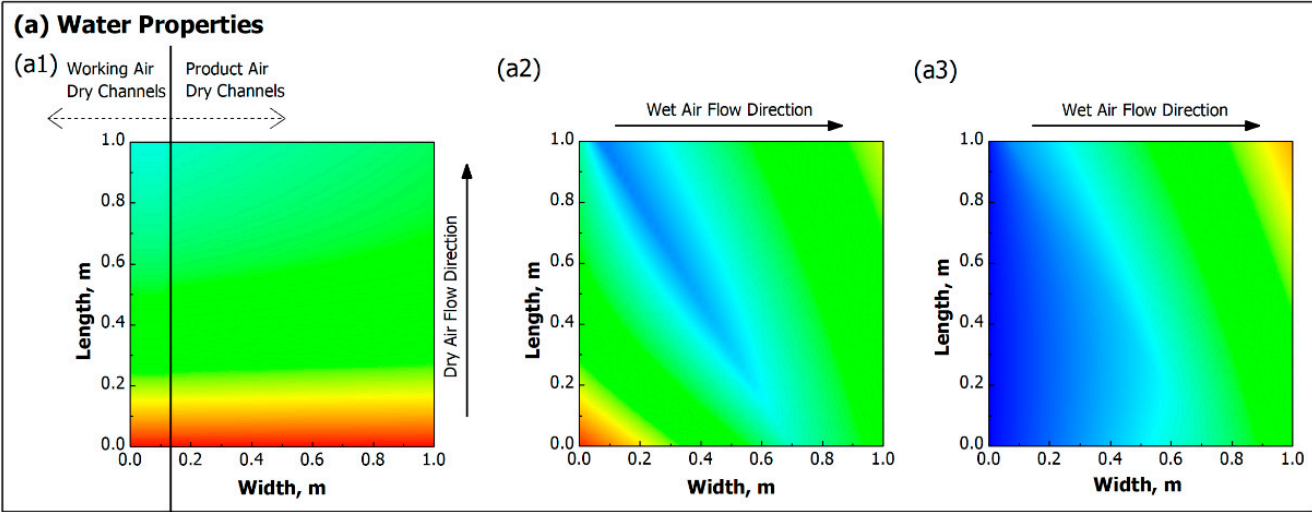

(b) CuO-Water Nanofluid Properties

(b1)

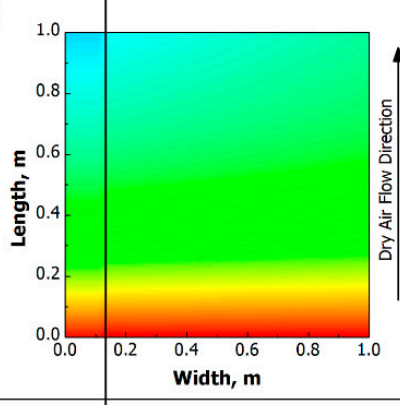

(b2)

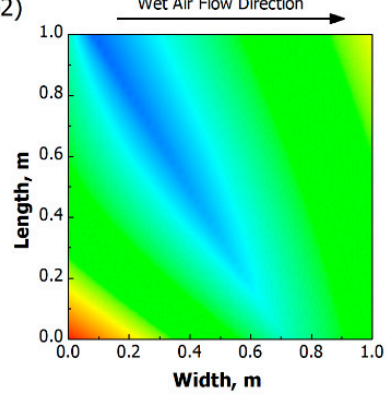

(b3)

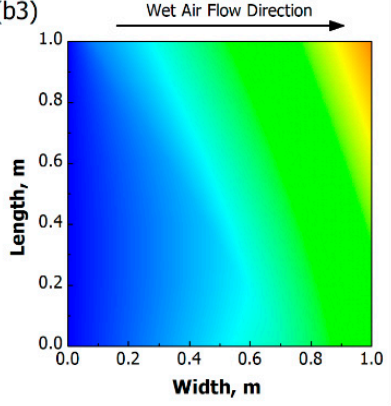

(c) $\mathrm{TiO}_{2}$-Water Nanofluid Properties

(c1)

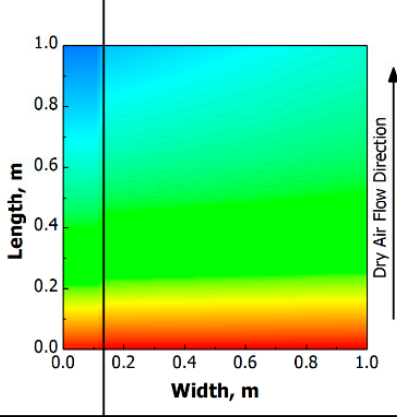

(c2)

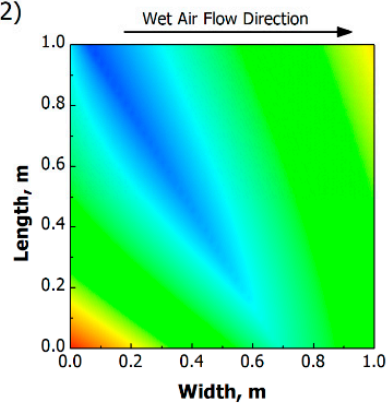

(c3)

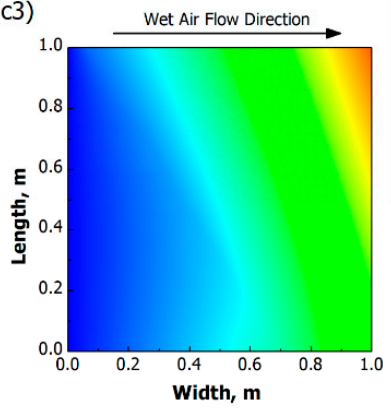

(d) $\mathrm{Al}_{2} \mathrm{O}_{3}$-Water Nanofluid Properties

(d1)

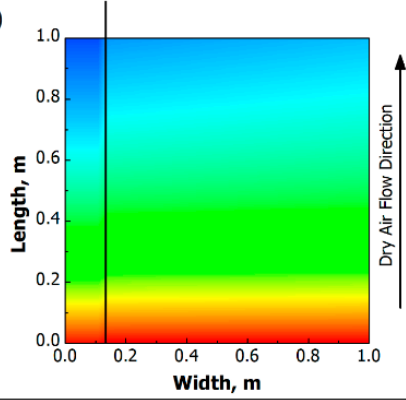

(d2)

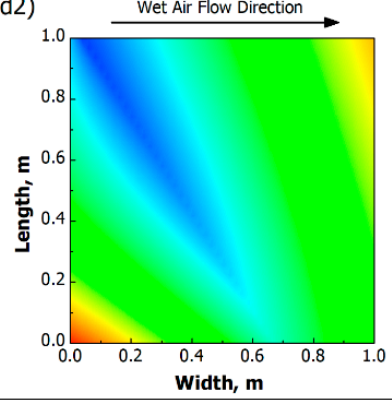

(d3)

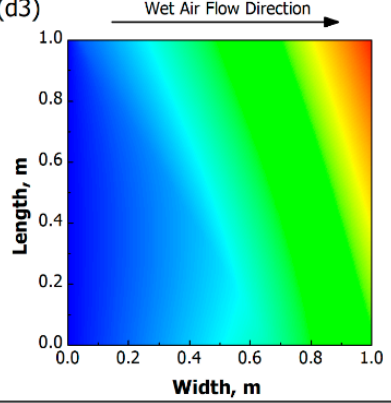

Figure 6. (a1-a3) Temperature distribution of product air and working air and humidity distribution of working air, respectively, using water properties. (b1-b3) Temperature distribution of product air and working air and humidity distribution of working air, respectively, using $\mathrm{CuO}-$ water nanofluid properties. (c1-c3) Temperature distribution of product air and working air and humidity distribution of working air, respectively, using $\mathrm{TiO}_{2}$-water nanofluid properties. (d1-d3) Temperature distribution of product air and working air and humidity distribution of working air, respectively, using $\mathrm{Al}_{2} \mathrm{O}_{3}$-water nanofluid properties. 
The differences in heat and mass transfer characteristics among all of these four kinds of evaporation media can also be described in terms of heat flux and water evaporation rate to better understand this behavior. For this purpose, simulations were conducted for the HMX using normal water properties as well as all three types of nanofluids; the results are reported in Figure 7. It can be observed that the heat flux and the water evaporation rate (WER) increase with the increase in inlet temperature. The working air in the wet channel has greater capacity to cause evaporation in the wet channel for high working air inlet temperatures and, as a result, the heat flux of the product air is increased. Similarly, the water evaporation rate is also high for high working air temperatures because air at higher temperature has a greater tendency to cause evaporation. However, the addition of the nanoparticles further enhances the heat flux of the product air [31] and the water evaporation rate [48] in the wet channel. The thermo-physical properties of the nanofluid based on alumina are higher as compared to those of the nanofluids based on copper oxide and titanium oxide; therefore, the heat flux and WER of the alumina-based nanofluid are the highest reported among all. Increases of $24.2 \%$ in the heat flux and $22.2 \%$ in the water evaporation rate are observed when using alumina nanofluid as compared to water at a temperature of $40{ }^{\circ} \mathrm{C}$.

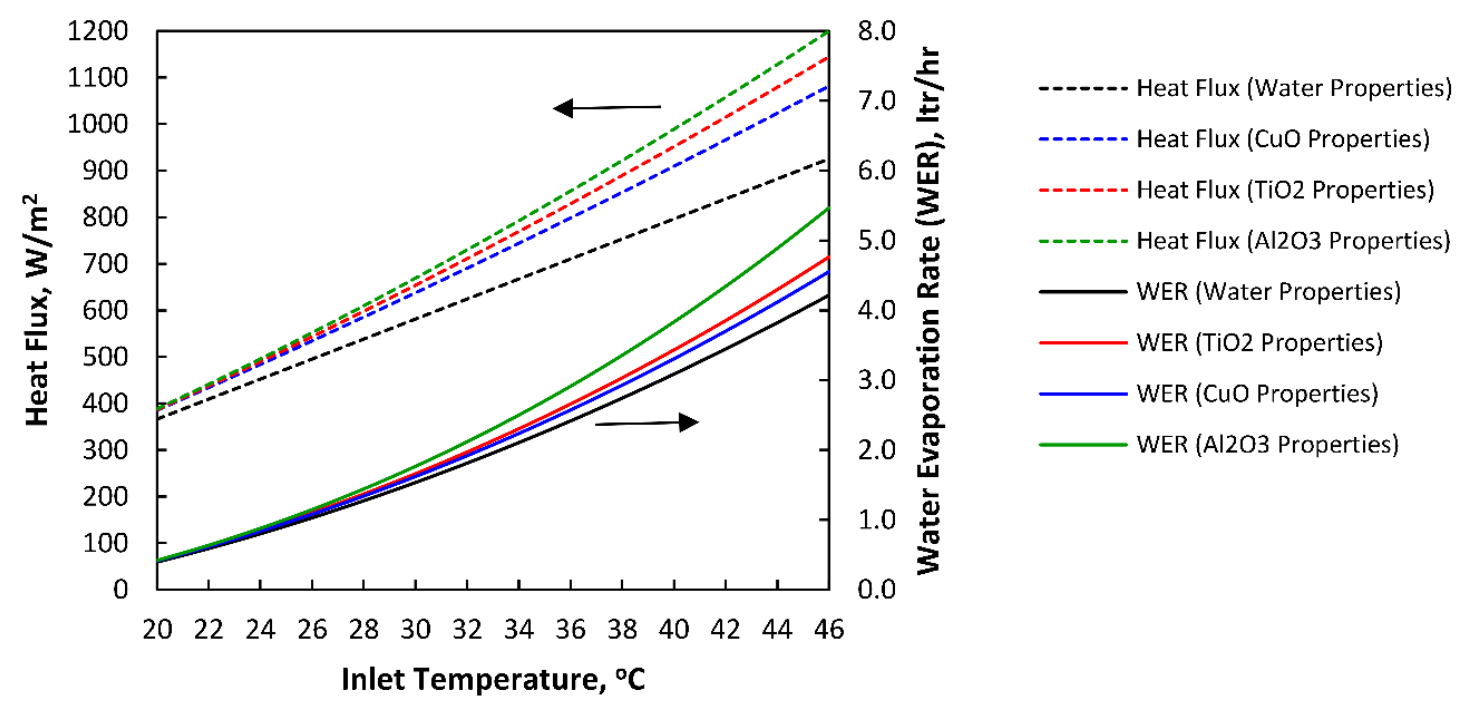

Figure 7. Influence of nanofluids on heat flux and water evaporation rate.

\subsection{Performance of HMX Considering Different Types of Nanofluids}

Figure 8 shows the influence of the inlet air temperature on the cooling effectiveness, cooling capacity, and energy efficiency ratio of the HMX along with the behavior of each type of nanofluid. It is observed that all performance parameters are increasing with the increase in temperature. This is justified by the conclusion drawn by Jradi et al. [49] that the temperature gradient between water and working air is high for a high range of temperatures of the inlet working air, therefore giving the potential for water evaporation.

One important conclusion that can be drawn from Figure $8 \mathrm{a}, \mathrm{b}$ is that cooling effectiveness is very sensitive to the addition of nanoparticles to the wet channel. The highest cooling effectiveness is observed for alumina-based nanofluid having a PER ranging from $2.34 \%$ to $19.24 \%$ for wet bulb effectiveness and $1.14 \%$ to $7.04 \%$ for dew point effectiveness for a temperature range of $20^{\circ} \mathrm{C}$ to $46^{\circ} \mathrm{C}$. The PER for alumina-based nanofluid is high because of its natural higher values of heat capacity, thermal diffusivity, and thermal conductivity as compared to the other two types of nanoparticles (Table 1). 

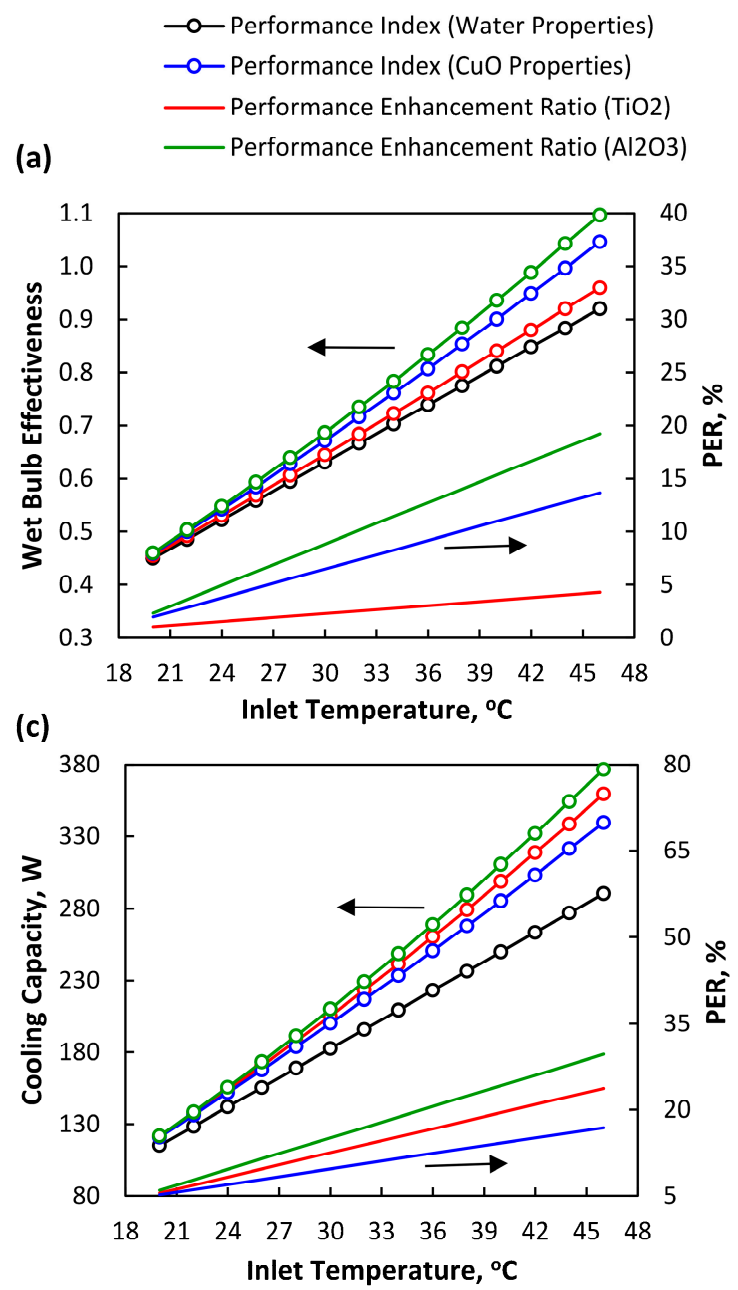

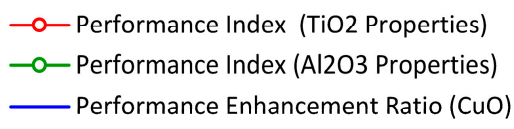

(b)
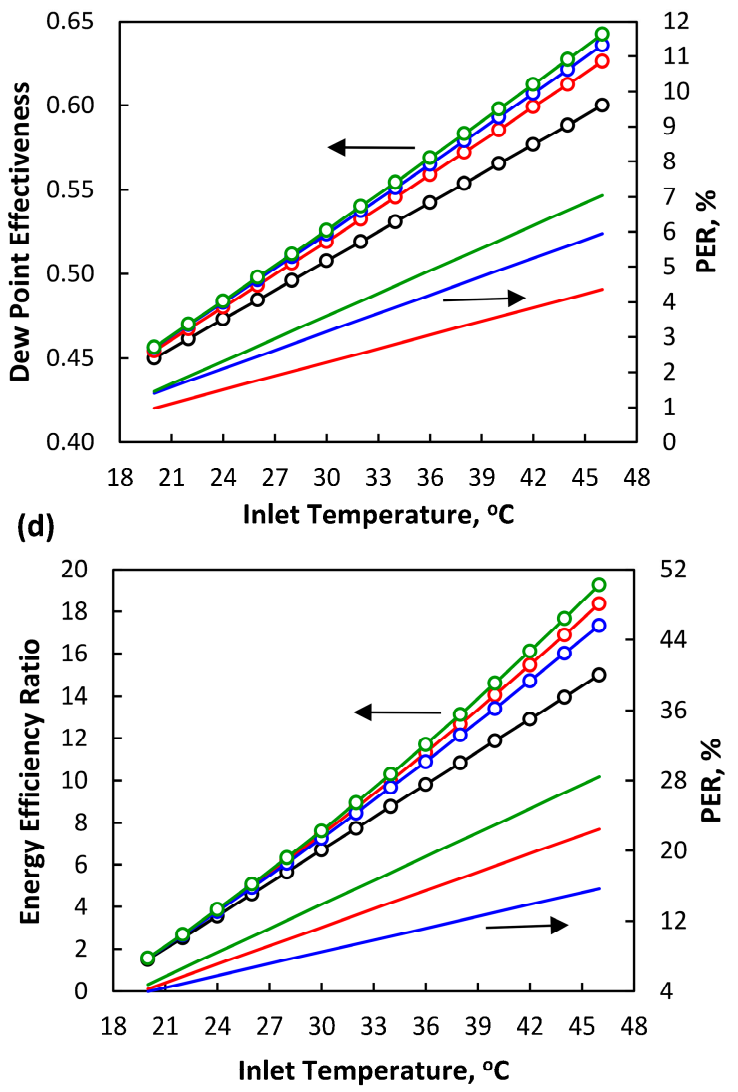

Figure 8. Influence of inlet temperature on (a) wet bulb effectiveness; (b) dew point effectiveness; (c) cooling capacity; and (d) energy efficiency ratio, with and without using nanofluids.

Figure 8c shows the variation of the cooling capacity and Figure 8d shows the energy efficiency ratio with temperature. The behavior of the different types of nanofluid and using water properties is also depicted in these figures. The cooling capacity shows an increasing trend with the increase in inlet air temperature. Anisimov et al. [27] suggested that a higher temperature of working air facilities the water evaporation phenomenon; therefore, it can carry more heat from the product air and, as a result, the cooling capacity increases with air temperature. Since the cooling capacity increases with increase in temperature, the EER also increases for the same blowing power as the mass flow rate remains the same. Furthermore, the addition of nanofluids greatly influences the cooling capacity and EER of the HMX. The PER of alumina-based nanofluid varies from $6.11 \%$ to $29.66 \%$ for the cooling capacity of the HMX and from $4.77 \%$ to $28.43 \%$ for the enhancement in energy efficiency ratio.

Results have shown that the alumina-based nanofluid has higher performance in terms of cooling effectiveness, cooling capacity, and energy efficiency ratio as compared to water and other types of nanofluids ( $\mathrm{CuO}$ - and $\mathrm{TiO}_{2}$-based). The literature [23] has also shown that the alumina-based nanofluid is the most viable option among current trending types of nanofluids because of its ease of availability, cost effectiveness, and preparation method. Therefore, an alumina-based nanofluid is the recommended option to be used in this configuration of a cross-flow HMX as an energy-efficient alternative. 


\subsection{Parametric Study for Alumina Oxide Nanoparticles in the Wet Channel of the HMX}

In this section, a parametric study was conducted specifically related to alumina nanoparticle properties and HMX performance parameters. The alumina oxide nanoparticle shows the highest performance index; therefore, further analysis was only carried out using this nanoparticle.

\subsubsection{Influence of Particle Volume Fraction on Cooling Performance}

Figure 9 shows the influence of particle volume fraction on the performance parameters of the HMX. The simulation was run between temperature and performance parameters for a particle volume fraction ranging between $0.2 \%$ and $1.8 \%$. Maheshwary et al. [24] proposed an analysis of the influence of the particle volume fraction on the pumping power. They found that pumping power is insignificant until $1.8 \%$ particle volume fraction and shoots up after this volume fraction; therefore, in this study, a maximum particle volume fraction of $1.8 \%$ was considered to keep the pumping power consistent by the addition of nanoparticles.

(a)
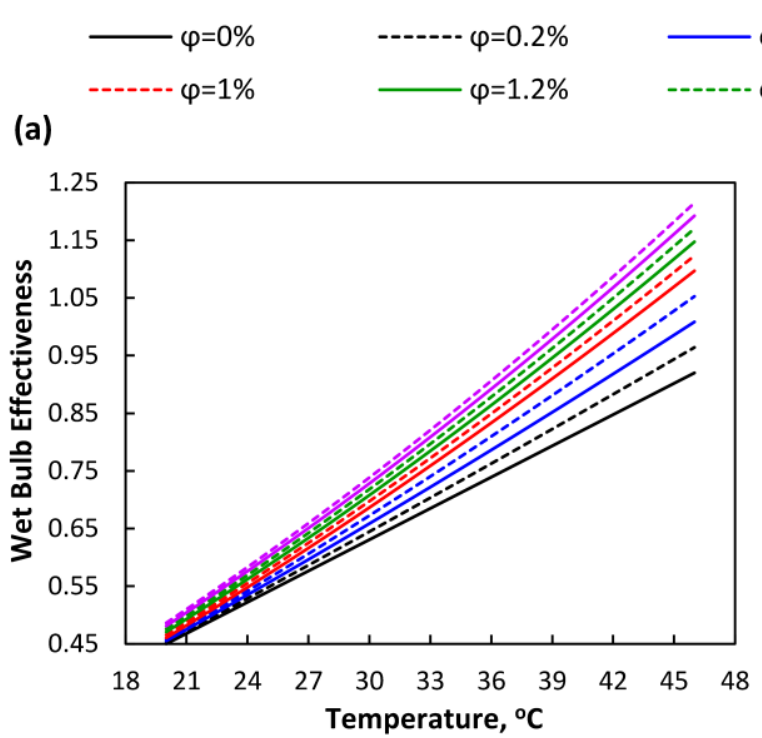

(c)

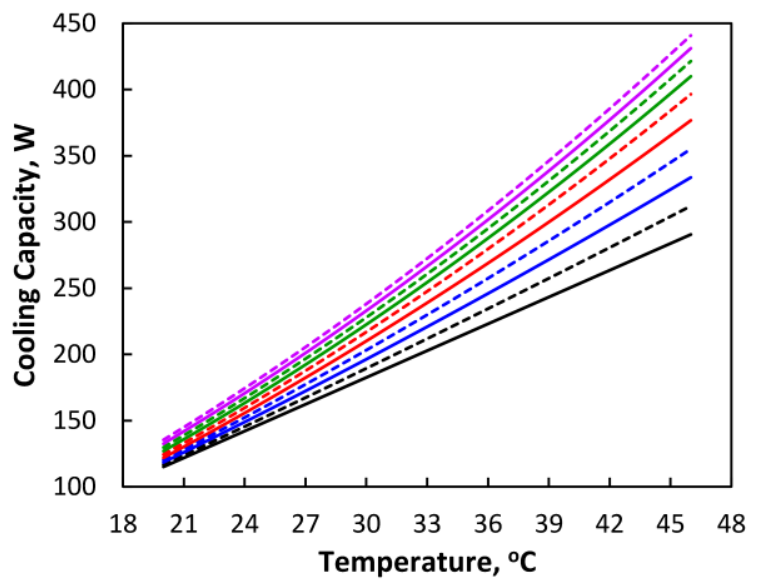

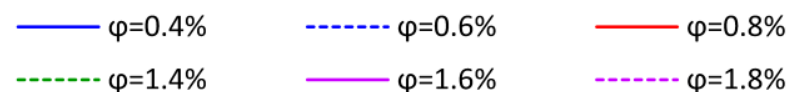

(b)

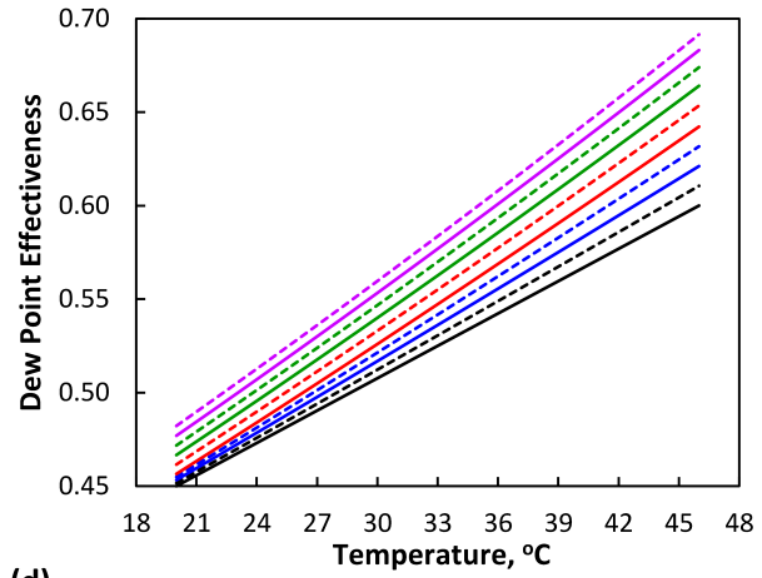

(d)

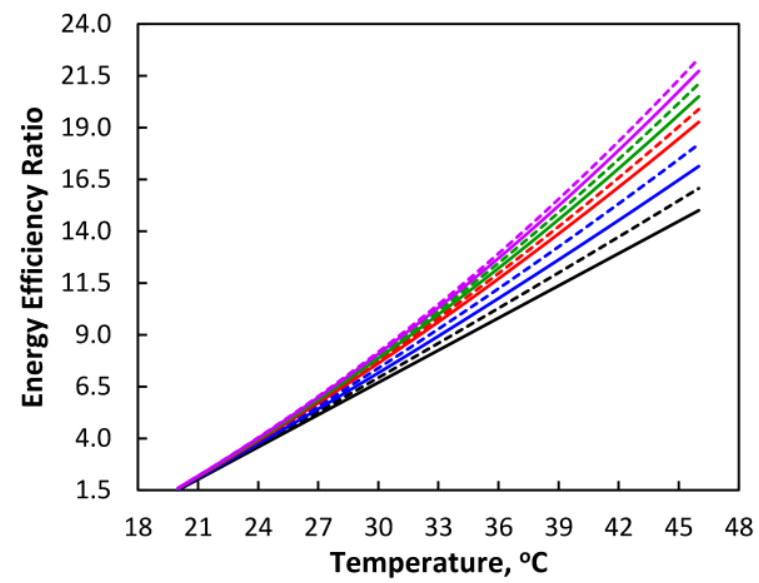

Figure 9. Influence of nanoparticle volume fraction on (a) wet bulb effectiveness; (b) dew point effectiveness; (c) cooling capacity; and (d) energy efficiency ratio.

It was observed that the performance parameters (cooling effectiveness, cooling capacity, and EER) are directly proportional to the particle volume fraction. The heat and mass transfer characteristics of the nanofluid are increased with the increment of the particle volume fraction because the density, viscosity, thermal diffusivity, and other parameters are calculated using the particle volume fraction. 
Furthermore, it is observed that the increment in the performance parameters is small after a particle volume fraction of $1 \%$. Therefore, it is suggested to use a maximum of $1 \%$ of alumina-based nanoparticles in the wet channel of the HMX.

\subsubsection{Influence of Particle Diameter on Cooling Performance}

The influence of the volume fraction was already noted in Section 5.3.1. However, the role of particle size at a given volume fraction is further analyzed here. For this purpose, the nanoparticle diameter was varied from $10 \mathrm{~nm}$ to $50 \mathrm{~nm}$, keeping the other parameters as mentioned in Table 7, and their influence on performance parameters is shown in Figure 10a,b.

(a)

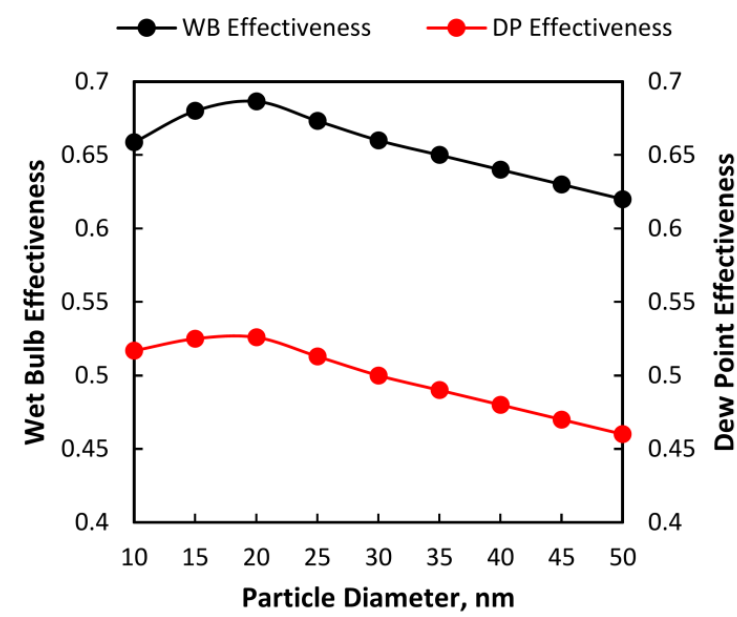

(b)

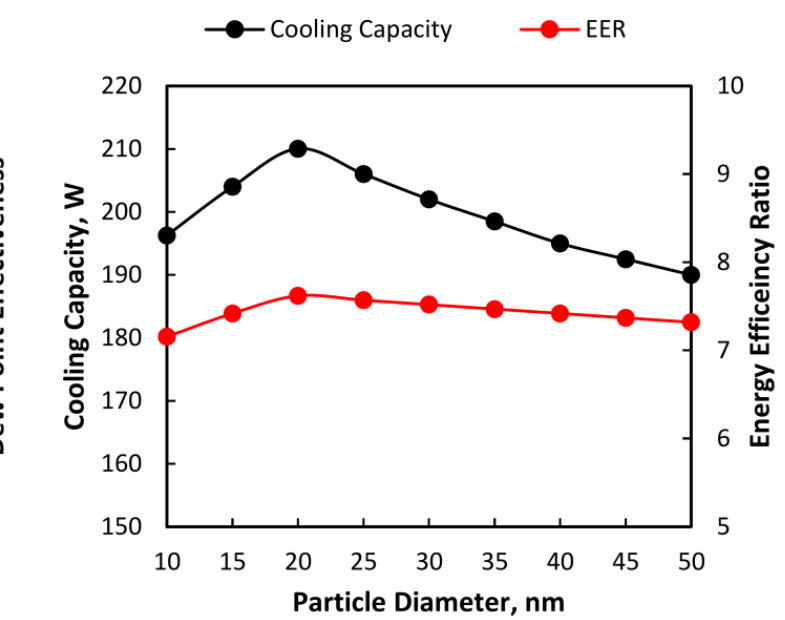

(c)

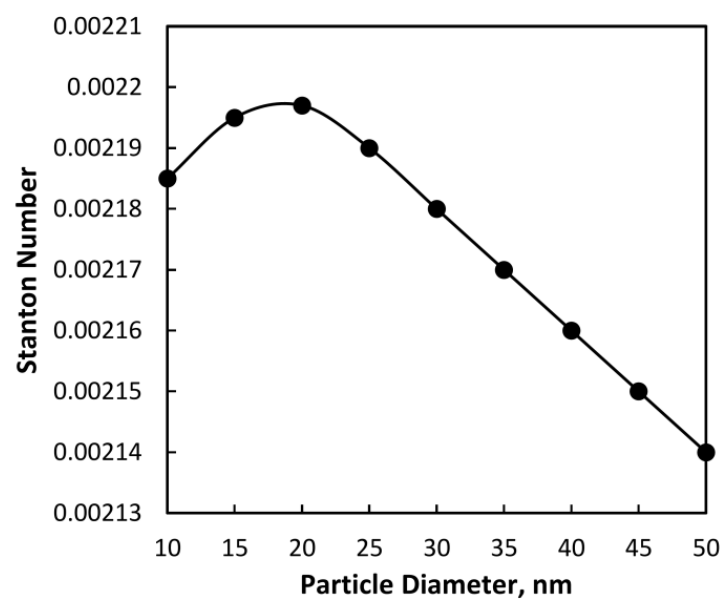

Figure 10. Influence of particle diameter on (a) wet bulb (WB), dew point (DP) cooling effectiveness; (b) cooling capacity, Energy Efficiency Ratio (EER); and (c) Stanton number.

It can be noted that the variation in the performance parameters is strongly dependent on particle size. The performance parameters are increasing until a particle diameter of around $20 \mathrm{~nm}$ and decrease afterwards. It is not directly apparent as to what causes the variation in performance parameters. Therefore, in order to investigate this behavior, a plot of Stanton numbers is shown in Figure 10c. The Stanton number signifies the influence of a particle as a heat storage unit compared to its convective heat transfer ability. It is quite clear that the Stanton number is also increasing up to a particle size of around $20 \mathrm{~nm}$ and decreases afterwards. This suggests a threshold of the Stanton number. For a particle size less than $20 \mathrm{~nm}$, the threshold of the Stanton number is not achieved; therefore, the performance parameters are increasing until the threshold is achieved $\left(d_{p}=20 n m\right)$ 
because the convective coefficient is increasing due to the increase in the size of the particle. However, for large particle size $\left(d_{p}>20 \mathrm{~nm}\right)$, the internal storage capacity of the particles increases significantly and reduces the convective heat transfer despite the increase in surface area. The change in the volume and surface area of the nanoparticle is quite detrimental to the cooling performance of the HMX, as suggested by the results.

\section{Summary and Conclusions}

Cross-flow indirect evaporative coolers are applied in residential and commercial buildings because of their high cooling capacity. Water is used as a refrigerant in such cooling devices, and in this work, the performance of a cross-flow indirect evaporative cooler was enhanced by replacing the water with a nanofluid. For this purpose, analysis was carried out using three different combinations of nanofluids including water-alumina, water-copper oxide, and water-titanium oxide. A mathematical model of the conventional cross-flow indirect evaporative cooler was solved coupled with previously established heat and mass transfer correlations of the nanofluids to evaluate the performance in terms of cooling capacity, cooling effectiveness, and energy efficiency ratio. The following are the key findings of the work:

(1) For an inlet air temperature of $40{ }^{\circ} \mathrm{C}$, the heat fluxes for the $\mathrm{Al}_{2} \mathrm{O}_{3}$-water, $\mathrm{CuO}$-water, and $\mathrm{TiO}_{2}$-water nanofluids are $24 \%, 14 \%$, and $19.5 \%$, respectively; these are more than the heat flux using water as an evaporating medium in the wet channel. Similarly, for an inlet air temperature of $40{ }^{\circ} \mathrm{C}$, the water evaporations rate increased by $24.4 \%, \sim 7 \%$, and $11 \%$ for $\mathrm{Al}_{2} \mathrm{O}_{3}$-water, $\mathrm{CuO}$-water, and $\mathrm{TiO}_{2}$-water nanofluids, respectively-more than for using water as an evaporating medium in the wet channel. Therefore, the $\mathrm{Al}_{2} \mathrm{O}_{3}$-water nanofluid combination is the most suitable.

(2) The highest performance was reported using $\mathrm{Al}_{2} \mathrm{O}_{3}$-water nanofluid as an evaporating medium in the wet channel. The performance enhancement achieved by utilizing this nanofluid as compared to water was a $2.34 \%$ to $19.24 \%$ increment in wet bulb effectiveness, $1.14 \%$ to $7.04 \%$ increment in dew point effectiveness, $6.11 \%$ to $29.66 \%$ increment in cooling capacity, and $4.77 \%$ to $28.43 \%$ increment in energy efficiency ratio for a temperature range between $20^{\circ} \mathrm{C}$ and $46{ }^{\circ} \mathrm{C}$.

(3) A particle volume concentration of $1 \%$ and a particle size diameter of $20 \mathrm{~nm}$ for the $\mathrm{Al}_{2} \mathrm{O}_{3}$-water nanofluid is the recommended option for the cross-flow heat and mass exchanger.

Author Contributions: Conceptualization, L.D. and V.C.; Data curation, C.L. and S.T.; Formal analysis, C.L. and S.T.; Methodology, C.L.; Project administration, L.D.; Software, C.L.; Writing—original draft, C.L.

Funding: This research received no external funding.

Acknowledgments: The authors are thankful to the kind reviewers for helping us in the improvement of this manuscript.

Conflicts of Interest: The authors declare no conflict of interest.

\section{Nomenclature}

$\begin{array}{ll}\text { A } & \text { Heat Transfer Surface Area, } \mathrm{m}^{2} \\ \mathrm{a} & \text { Height, } \mathrm{m} \\ \mathrm{b} & \text { Width, } \mathrm{m} \\ \mathrm{c}_{\mathrm{p}} & \text { Specific Heat of Fluid, } \mathrm{J} /(\mathrm{kg} \cdot \mathrm{K}) \\ \mathrm{D}_{\mathrm{h}} & \text { Hydraulic Diameter, } \mathrm{m} \\ \mathrm{d} & \text { Molecule Diameter, } \mathrm{m} \\ \mathrm{H} & \text { Enthalpy, } \mathrm{kJ} / \mathrm{kg} \\ \mathrm{h} & \text { Convective Heat Transfer Coefficient, } \mathrm{W} /\left(\mathrm{m}^{2} \cdot \mathrm{K}\right) \\ \mathrm{h}_{\mathrm{m}} & \text { Convective Mass Transfer Coefficient, }\left(\mathrm{kg} \cdot \mathrm{m}^{2}\right) / \mathrm{s} \\ \mathrm{i}_{\mathrm{v}} & \text { Latent Heat of Evaporation, } \mathrm{kJ} / \mathrm{kg} \\ \mathrm{k}_{\mathrm{f}} & \text { Thermal Conductivity, } \mathrm{W} /(\mathrm{m} \cdot \mathrm{K}) \\ \mathrm{L} & \text { Length of Channel, } \mathrm{m} \\ \mathrm{m} & \text { Mass Flow Rate of Fluid, } \mathrm{kg} / \mathrm{s}\end{array}$




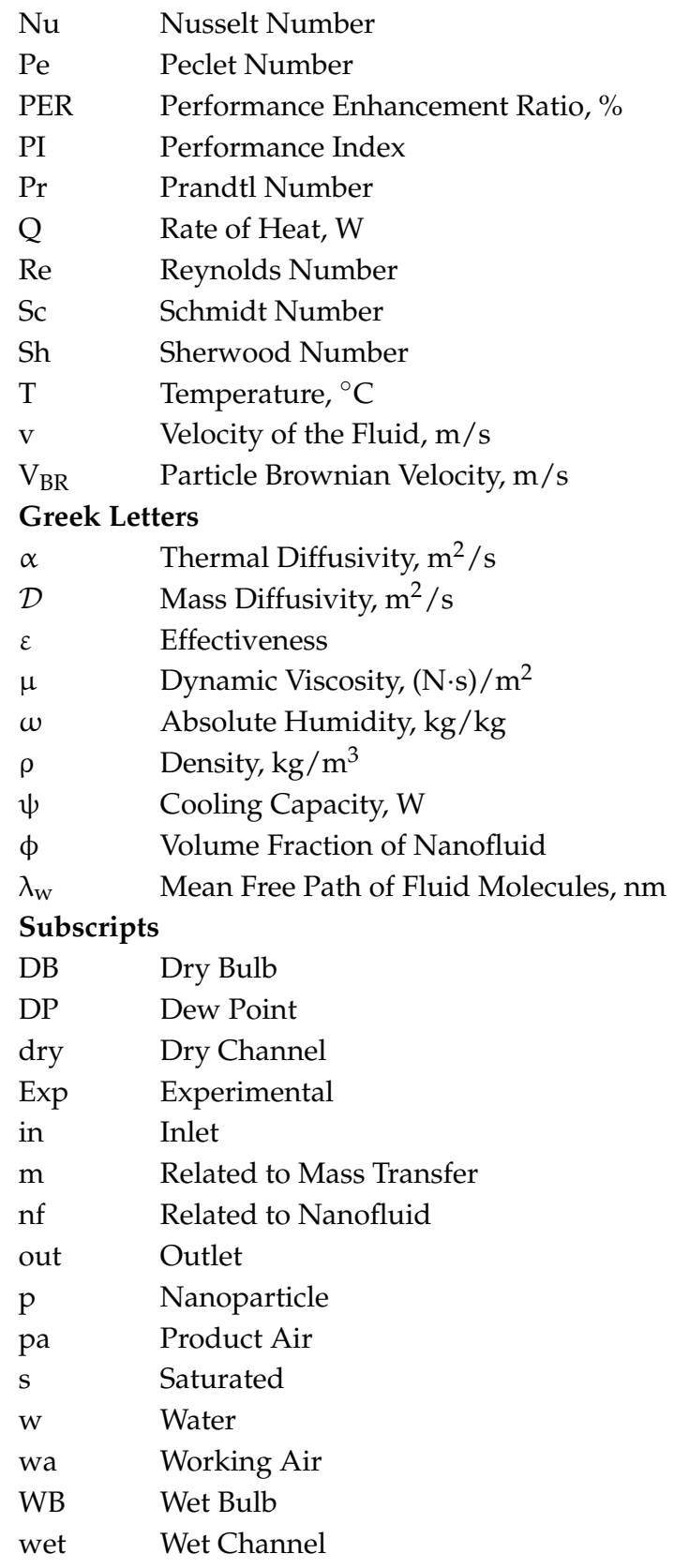

\section{References}

1. Emdadi, Z.; Asim, N.; Yarmo, M.A.; Shamsudin, R.; Mohammad, M.; Sopian, K. Green material prospects for passive evaporative cooling systems: Geopolymers. Energies 2016, 9. [CrossRef]

2. Martínez, P.J.; Llorca, C.; Pla, J.A.; Marténez, P. Experimental validation of the simulation model of a DOAS equipped with a desiccant wheel and a vapor compression refrigeration system. Energies 2017, 10, 1330. [CrossRef]

3. Ma, Y.; Saha, S.C.; Miller, W.; Guan, L. Parametric analysis of design parameter effects on the performance of a solar desiccant evaporative cooling system in brisbane, Australia. Energies 2017, 10, 849. [CrossRef]

4. Tariq, R.; Sheikh, N.A.; Xamán, J.; Bassam, A. An innovative air saturator for humidification-dehumidification desalination application. Appl. Energy 2018, 228, 789-807. [CrossRef]

5. Tariq, R.; Sheikh, N.A. Numerical heat transfer analysis of Maisotsenko Humid Air Bottoming Cycle-A study towards the optimization of the air-water mixture at bottoming turbine inlet. Appl. Therm. Eng. 2018, 133, 49-60. [CrossRef] 
6. Noroozi, A.; Veneris, Y.S. Thermal Assessment of a Novel Combine Evaporative Cooling Wind Catcher. Energies 2018, 11, 442. [CrossRef]

7. Li, S.; Jeong, J.-W. Energy Performance of Liquid Desiccant and Evaporative Cooling-Assisted 100\% Outdoor Air Systems under Various Climatic Conditions. Energies 2018, 11, 1377. [CrossRef]

8. Boukhanouf, R.; Alharbi, A.; Ibrahim, H.G.; Amer, O.; Worall, M. Computer modelling and experimental investigation of building integrated sub-wet bulb temperature evaporative cooling system. Appl. Therm. Eng. 2017, 115, 201-211. [CrossRef]

9. Lin, J.; Wang, R.Z.; Kumja, M.; Bui, T.D.; Chua, K.J. Modelling and experimental investigation of the cross-flow dew point evaporative cooler with and without dehumidification. Appl. Therm. Eng. 2017, 121, 1-13. [CrossRef]

10. Fakhrabadi, F.; Kowsary, F. Optimal design of a regenerative heat and mass exchanger for indirect evaporative cooling. Appl. Therm. Eng. 2016, 102, 1384-1394. [CrossRef]

11. Tariq, R.; Zhan, C.; Zhao, X.; Sheikh, N.A. Numerical study of a regenerative counter flow evaporative cooler using alumina nanoparticles in wet channel. Energy Build. 2018, 169, 430-443. [CrossRef]

12. Pandelidis, D.; Anisimov, S.; Rajski, K.; Brychcy, E.; Sidorczyk, M. Performance comparison of the advanced indirect evaporative air coolers. Energy 2017, 135, 138-152. [CrossRef]

13. Khalid, O.; Ali, M.; Sheikh, N.A.; Ali, H.M.; Shehryar, M. Experimental analysis of an improved Maisotsenko cycle design under low velocity conditions. Appl. Therm. Eng. 2016, 95, 288-295. [CrossRef]

14. Zhan, C.; Zhao, X.; Smith, S.; Riffat, S.B. Numerical study of a M-cycle cross-flow heat exchanger for indirect evaporative cooling. Build. Environ. 2011,46, 657-668. [CrossRef]

15. Zhan, C.; Duan, Z.; Zhao, X.; Smith, S.; Jin, H.; Riffat, S. Comparative study of the performance of the M-cycle counter-flow and cross-flow heat exchangers for indirect evaporative cooling - Paving the path toward sustainable cooling of buildings. Energy 2011, 36, 6790-6805. [CrossRef]

16. Anisimov, S.; Pandelidis, D.; Danielewicz, J. Numerical analysis of selected evaporative exchangers with the Maisotsenko cycle. Energy Convers. Manag. 2014, 88, 426-441. [CrossRef]

17. Pandelidis, D.; Anisimov, S.; Drag, P. Performance comparison between selected evaporative air coolers. Energies 2017, 10. [CrossRef]

18. Xu, P.; Ma, X.; Zhao, X.; Fancey, K.S. Experimental investigation on performance of fabrics for indirect evaporative cooling applications. Build. Environ. 2016, 110, 104-114. [CrossRef]

19. Duan, Z.; Zhao, X.; Li, J. Design, fabrication and performance evaluation of a compact regenerative evaporative cooler: Towards low energy cooling for buildings. Energy 2017, 140, 506-519. [CrossRef]

20. Xu, P.; Ma, X.; Zhao, X.; Fancey, K. Experimental investigation of a super performance dew point air cooler. Appl. Energy 2017, 203, 761-777.

21. Lee, J.; Lee, D.Y. Experimental study of a counter flow regenerative evaporative cooler with finned channels. Int. J. Heat Mass Transf. 2013, 65, 173-179. [CrossRef]

22. Weerts, B.A. NSIDC Green Data Center Project: Coolerado and Modeling an Application of the Maisotsenko Cycle. Master's Thesis, University of Colorado, Boulder, CO, USA, 2012.

23. Pinto, R.V.; Fiorelli, F.A.S. Review of the mechanisms responsible for heat transfer enhancement using nanofluids. Appl. Therm. Eng. 2016, 108, 720-739. [CrossRef]

24. Maheshwary, P.B.; Handa, C.C.; Nemade, K.R. A comprehensive study of effect of concentration, particle size and particle shape on thermal conductivity of titania/water based nanofluid. Appl. Therm. Eng. 2017, 199, 79-88. [CrossRef]

25. Albadr, J.; Tayal, S.; Alasadi, M. Case Studies in Thermal Engineering Heat transfer through heat exchanger using Al 2 O 3 nanofluid at different concentrations. Case Stud. Therm. Eng. 2013, 1, 38-44. [CrossRef]

26. Colangelo, G.; Favale, E.; Milanese, M.; de Risi, A.; Laforgia, D. Cooling of electronic devices: Nanofluids contribution. Appl. Therm. Eng. 2017, 127, 421-435. [CrossRef]

27. Anisimov, S.; Pandelidis, D. Numerical study of the Maisotsenko cycle heat and mass exchanger. Int. J. Heat Mass Transf. 2014, 75, 75-96. [CrossRef]

28. Kakaç, S.; Pramuanjaroenkij, A. Single-phase and two-phase treatments of convective heat transfer enhancement with nanofluids-A state-of-the-art review. Int. J. Therm. Sci. 2016, 100, 75-97. [CrossRef]

29. Vanaki, S.M.; Ganesan, P.; Mohammed, H.A. Numerical study of convective heat transfer of nanofluids: A review. Renew. Sustain. Energy Rev. 2016, 54, 1212-1239. [CrossRef] 
30. Beck, M.P.; Yuan, Y.; Warrier, P.; Teja, A.S. The effect of particle size on the thermal conductivity of alumina nanofluids. J. Nanopart. Res. 2009, 11, 1129-1136. [CrossRef]

31. Chiam, H.W.; Azmi, W.H.; Adam, N.M.; Ari, M.K.A.M. Numerical study of nanofluid heat transfer for different tube geometries-A comprehensive review on performance. Int. Commun. Heat Mass Trans. 2017, 86, 60-70. [CrossRef]

32. Godson, L.; Raja, B.; Lal, D.M.; Wongwises, S. Enhancement of heat transfer using nanofluids-An overview. Renew. Sustain. Energy Rev. 2010, 14, 629-641. [CrossRef]

33. Sieder, E.N.; Tate, G.E. Heat Transfer and Pressure Drop of Liquids in Tubes. Ind. Eng. Chem. 1936, 28, 1429-1435. [CrossRef]

34. Singh, P.; Kumar, M. Mass transfer in MHD flow of alumina water nanofluid over a flat plate under slip conditions. Alexandria Eng. J. 2015, 54, 383-387. [CrossRef]

35. Cussler, E.L. Diffusion: Mass Transfer in Fluid Systems; Cambridge University Press: Cambridge, UK, 1997.

36. Welty, J.; Wicks, C.; Wilson, R.; Rorrer, G. Fundamentals of Momentum, heat, and Mass Transfer; John Wiley and Sons: Hoboken, NJ, USA, 2008.

37. Yang, L.; Xu, J.; Du, K.; Zhang, X. Recent developments on viscosity and thermal conductivity of nanofluids. Powder Technol. 2017, 317, 348-369. [CrossRef]

38. Xuan, Y.; Roetzel, W. Conceptions for heat transfer correlation of nanofluids. Int. J. Heat Mass Transf. 2000, 43, 3701-3707. [CrossRef]

39. Li, Q.; Xuan, Y. Convective heat transfer and flow characteristics of Cu-water nanofluid. Sci. China Ser. E Technol. Sci. 2002, 45, 408-416.

40. Chon, C.H.; Kihm, K.D.; Lee, S.P.; Choi, S.U.S. Empirical correlation finding the role of temperature and particle size for nanofluid $\left(\mathrm{Al}_{2} \mathrm{O}_{3}\right)$ thermal conductivity enhancement. Appl. Phys. Lett. 2005, 87. [CrossRef]

41. Incropera, F.P.; DeWitt, D.P.; Bergman, T.L.; Lavine, A.S. Fundamentals of Heat and Mass Transfer; John Wiley \& Sons: Hoboken, NJ, USA, 2007.

42. Pandelidis, D.; Anisimov, S.; Worek, W.M. Comparison study of the counter-flow regenerative evaporative heat exchangers with numerical methods. Appl. Therm. Eng. 2015, 84, 211-224. [CrossRef]

43. Maisotsenko, V.E.; Gillan, L.; Heaton, T.L.; Gillan, A.D. Method and Plate Apparatus for Dew Point Evaporative Cooler. U.S. Patent 09,966,928, 27 September 2001.

44. Catalogue Data of the Fiber Heat and Mass Exchanger (Natural Air Conditioner); ISAW Corporation Limited: Hangzhou, China, 2005.

45. Qiu, G. A Novel Evaporative/Desiccant Cooling System. Ph.D. Thesis, University of Nottingham, Nottingham, UK, 2007.

46. EES: Engineering Equation Solver I F-Chart Software: Engineering Software. Available online: http:/ / www. fchart.com/ees/ (accessed on 28 September 2018).

47. Bolotin, S.; Vager, B.; Vasilijev, V. Comparative analysis of the cross-flow indirect evaporative air coolers. Int. J. Heat Mass Transf. 2015, 88, 224-235. [CrossRef]

48. Ashrafmansouri, S.S.; Nasr Esfahany, M. Mass transfer in nanofluids: A review. Int. J. Therm. Sci. 2014, 82, 84-90. [CrossRef]

49. Jradi, M.; Riffat, S. Experimental and numerical investigation of a dew-point cooling system for thermal comfort in buildings. Appl. Energy 2014, 132, 524-535. [CrossRef]

(C) 2018 by the authors. Licensee MDPI, Basel, Switzerland. This article is an open access article distributed under the terms and conditions of the Creative Commons Attribution (CC BY) license (http://creativecommons.org/licenses/by/4.0/). 